\title{
THE ITSAQ GNEISS COMPLEX OF GREENLAND: EPISODIC 3900 TO 3660 Ma JUVENILE CRUST FORMATION AND RECYCLING IN THE 3660 TO 3600 Ma ISUKASIAN OROGENY
}

\author{
ALLEN P. NUTMAN*, ${ }^{\dagger}$, VICKIE C. BENNETT**, CLARK R. L. FRIEND***, \\ HIROSHI HIDAKA ${ }^{\S}$, KEEWOOK YI ${ }^{\S \S}$, SEUNG RYEOL LEE ${ }^{\S \S \S}$, \\ and TOMOYUKI KAMIICHI ${ }^{\S}$
}

\begin{abstract}
From the $3000 \mathrm{~km}^{2}$ Eoarchean Itsaq Gneiss Complex (IGC) of Greenland, zircon U-Pb dating of numerous meta-granitoid and orthogneiss samples is integrated with geologic observations, whole rock geochemistry and a strategic subset of zircon $\mathrm{Hf}$ and whole rock $\mathrm{Nd}$ isotopic measurements. This shows that there are multiple episodes of TTG suite formation from $\sim 3890$ to $3660 \mathrm{Ma}$, characterized by zircon initial $\varepsilon_{\mathrm{Hf}} \approx 0$ and whole rock initial $\varepsilon_{\mathrm{Nd}}$ of $>+2$. These rocks mostly have geochemical signatures of partial melting of eclogitized mafic sources, with a subset of high magnesian, low silica rocks indicating fusion by fluid fluxing of upper mantle sources. The TTG suites are accompanied by slightly older gabbros, basalts and andesites, which have geochemical signatures pointing to magmas originating from fluid fluxing of upper mantle sources. The data show the formation of juvenile crust domains in several discrete events from $\sim 3900$ to 3660 Ma, probably at convergent plate boundaries in an environment analogous, but not identical to, modern island arcs.
\end{abstract}

In the Isua area, a northern $\sim 3700$ Ma terrane formed distal from a predominantly $\sim 3800$ Ma terrane. These terranes were juxtaposed between 3680 and 3660 $\mathrm{Ma}$-respectively the age of the youngest rocks unique to the northern terrane and the lithologically distinctive ultramafic-granitic Inaluk dykes common to both terranes. This shows the assembly of different domains of juvenile rocks to form a more expansive domain of "continental" crust. A rare occurrence of high-pressure granulite is dated at $\sim 3660 \mathrm{Ma}$, demonstrating that assembly involved tectonic crustal thickening.

This continental crust was then reworked in the 3660 to 3600 Ma Isukasian orogeny. In the northern part of the Isua area, 3660 to 3600 Ma granites were emplaced into $\sim 3700$ Ma tonalites. The earliest granites are nebulous, and sigmoidal schlieric inclusions within them demonstrate ductile extension. Younger granite sheets were emplaced into extensional ductile-brittle fractures. These granite-tonalite relationships are overprinted by widespread development of late Eoarchean (pre-3500 Ma Ameralik dyke) brittle-ductile extensional cataclastic textures, together demonstrating that extension was polybaric. The southern part of the Isua area largely escaped $\mathbf{3 6 6 0}$ to $3600 \mathrm{Ma}$ high temperature processes and has sparse granite sheets commonly focused into coeval shear zones. In the rest of the complex, deeper crustal levels during the Isukasian orogeny are widely preserved. These experienced upper amphibolite to granulite facies moderate- to low-pressure syn-kinematic metamorphism, forming complex migmatites rich in granitic-trondhjemitic neosome. The migmatites were intruded by composite ferrogabbro and granite bodies, in which syn-magmatic extensional features are locally preserved. Thus 3660 to 3600 Ma crustal recycling involved elevated crustal thermal gradients in an extensional regime. Crustal melts formed in

\footnotetext{
* GeoQuEST Research Centre, School of Earth \& Environmental Sciences, University of Wollongong, Wollongong, NSW 2522, Australia

** Research School of Earth Sciences, Australian National University, Canberra, ACT 0200, Australia

*** Glendale, Albury View, Tiddington, Oxon, OX9 2LQ, United Kingdom

$\$$ Department of Earth and Planetary Systems Sciences, University of Hiroshima, 1-3-1 Kagamiyama, Higashi-Hiroshima 739-8526, Japan

$\$ \$$ Geological Research Division, Korea Institute of Geoscience and Mineral Resources, Daejeon 305-350, Korea

$\$ \$ \$$ Korean Institute of Geoscience and Mineral Resources, Daejeon 305-350, Korea

+ Corresponding author: anutman@uow.edu.au
} 
the Isukasian orogeny have zircon initial $\varepsilon_{\mathrm{Hf}}<0$ and whole rock initial $\varepsilon_{\mathrm{Nd}}$ of $\leq 0$, showing incorporation of slightly older Eoarchean juvenile crust. A Phanerozoic example of collisional orogeny followed by crustal thinning is explored as an analog for the Isukasian orogeny.

Key words: Itsaq gneiss complex (Greenland), Eoarchean, juvenile crust, crustal recycling, convergent plate boundaries, crustal extension, Isukasian orogeny

\section{INTRODUCTION}

Known Eoarchean (4000-3600 Ma) rocks comprise only about 1 millionth of Earth's surface, which reflects the small volume that has survived more than 3.5 billion years of plate tectonics, weathering and erosion (Nutman, 2006 and references therein). These rocks occur in several gneiss complexes scattered around the globe, and they all show broadly similar lithologies and evolutionary histories (see Schiøtte and others, 1989a; Nutman and others, 1991, 1996; Kinny and Nutman, 1996; Bowring and Williams, 1999; Iizuka and others, 2007; Liu and others, 2007; O'Neil and others, 2007 and Horie and others, 2010, for accounts of the most studied occurrences). However the Itsaq Gneiss Complex (IGC) of the Nuuk district of southern West Greenland (fig. 1; Nutman and others, 1996 and references therein) is the best exposed, and contains some rare areas of low total strain and relatively low (epidoteamphibolite facies) metamorphic overprint. The combination of these factors means that, since the antiquity of the Greenland rocks was first demonstrated by McGregor (1968, 1973), Black and others (1971), Moorbath and others (1972) and Baadsgaard $(1973)^{1}$, they have remained at the forefront in understanding the Eoarchean Earth.

This paper takes a holistic view of knowledge on the Eoarchean Earth accrued from the IGC and focuses on the formation environment of juvenile crust from $\sim 3900$ to $3660 \mathrm{Ma}$ and the nature and setting of its recycling in the Isukasian orogeny between 3660 to $3600 \mathrm{Ma}$. Although we synthesise much published data from different sources, we also complete a U-Pb zircon SHRIMP geochronological survey of meta-granitoids and orthogneisses throughout the IGC (over 160 samples) and provide new geological information and zircon dating that gives greater insight on the 3660 to $3600 \mathrm{Ma}$ Isukasian orogeny. Appraisal of the IGC points to $>200$ million years of juvenile crust formation occurring in arc-like intra-oceanic settings ( $\geq 3900 \mathrm{Ma}$ to $\sim 3660 \mathrm{Ma}$ ), then an orogeny starting with collision and crustal thickening, followed by crustal thinning with an elevated geothermal gradient. Figure 2 is a schematic flow diagram illustrating the early period of juvenile crust production, followed by orogeny starting with tectonic crustal thickening and then by crustal recycling coeval with extension. Figures 3A-3C present schematic cross sections through the upper, middle and lower parts of the crust at the end of the orogeny, whereas figure 3D shows how these sections might be related. This pattern of crust formation and reworking has similarities to that seen in Phanerozoic terranes, and implicates plate tectonic processes in the formation of Eoarchean crust. A possible Phanerozoic analog for the Isukasian orogeny is explored.

\footnotetext{
${ }^{1}$ These rocks were originally known as the Amîtsoq gneisses (McGregor, 1973), with the plurality deliberately chosen to indicate their already recognized lithological diversity. This term was modified into the singular Amitsoq gneiss in some later publications (for example, Kamber and Moorbath, 1998) — perhaps compatible with the interpretations therein of these rocks as a product of a single crust-forming event, rather than having formed via a more protracted series of unrelated events. In order to counter any perception of uniformity in these rocks, the late Vic McGregor and his colleagues introduced the term Itsaq Gneiss Complex (Nutman, and others, 1996; with Itsaq being Greenlandic for ancient thing).
} 


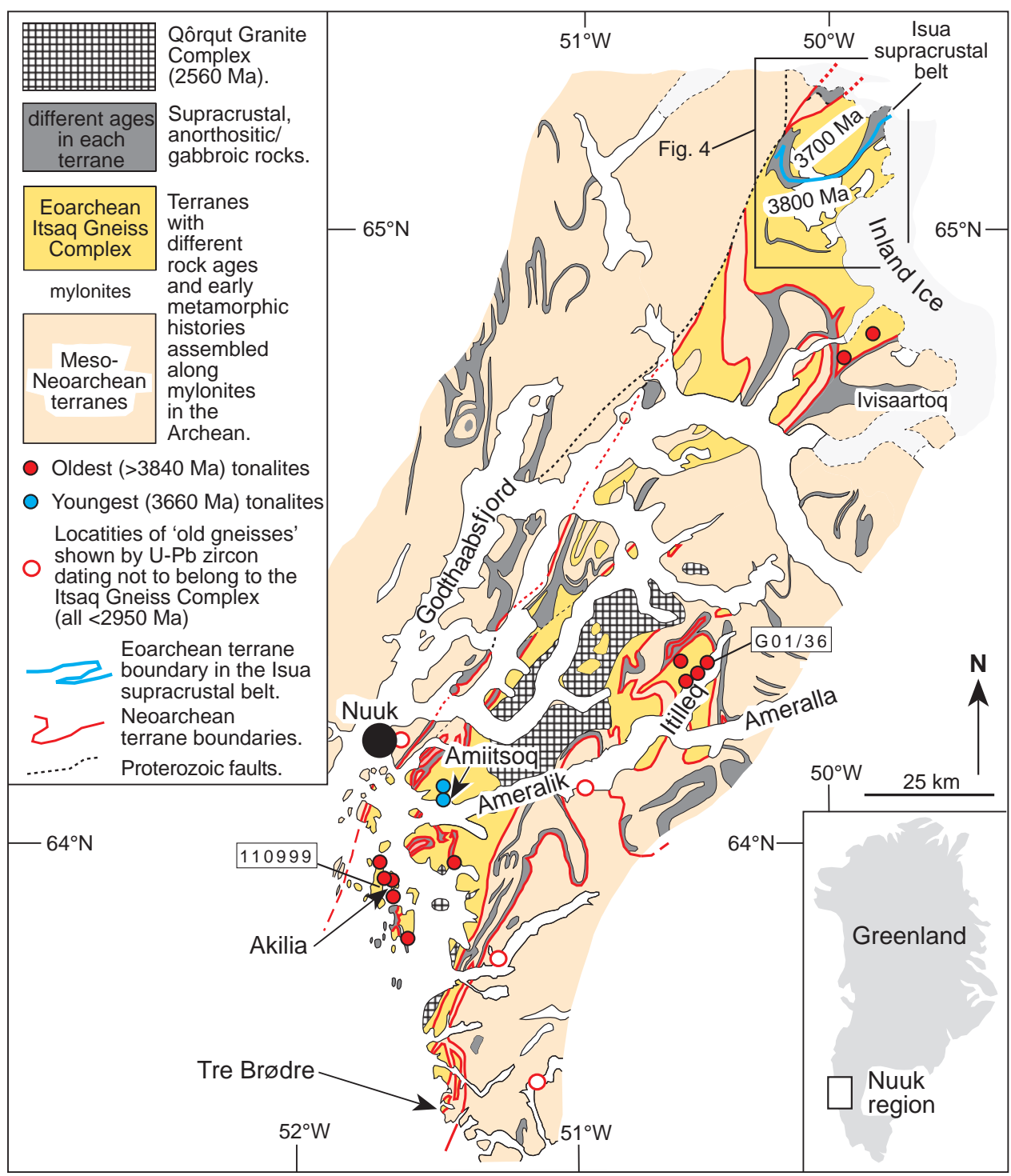

Fig. 1. Geological map of the Nuuk region, displaying the Eoarchean Itsaq Gneiss Complex, and summary of SHRIMP U/Pb zircon results on TTG rocks, showing the location of the oldest ( $\geq 3850 \mathrm{Ma}$ ) and youngest (3660 Ma) components. Localities mentioned in the text are indicated.

THE ITSAQ GNEISS COMPLEX

\section{Overview}

Much of the IGC was affected by 3660 to 3600 Ma high-grade metamorphism and ductile deformation (Griffin and others, 1980; Nutman and others, 1996; Friend and Nutman 2005a) such that by 3600 Ma the existing lithologies had been widely converted into strongly deformed multi-component amphibolite-granulite facies gneisses (fig. 4A). An additional complication in interpreting the IGC is that it occurs as tectonic slivers bounded by folded Meso- and Neoarchean meta-mylonites, within a 


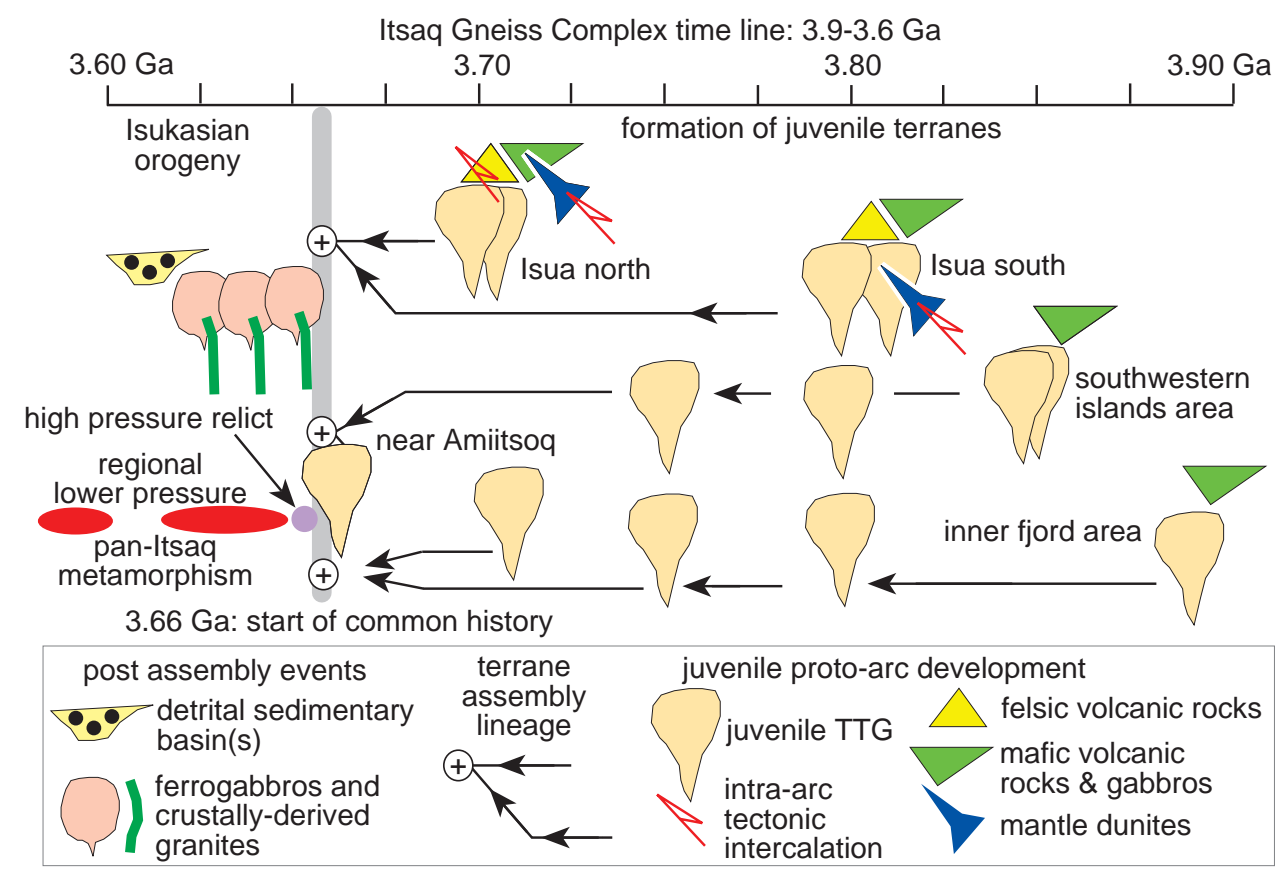

Fig. 2. Timeline for the evolution of the Itsaq Gneiss Complex from 3900 to $3600 \mathrm{Ma}$. This is based on $\mathrm{U}-\mathrm{Pb}$ zircon dating of more than 160 rocks integrated with geological mapping.

collage of younger Archean terranes that were assembled into their present configuration by the end of the Archean (Friend and others, 1987, 1988; Nutman and others, 1989; Crowley, 2002; Friend and Nutman, 2005b; Nutman and Friend, 2007). Thus the Eoarchean rocks are allochthons of mainly strongly deformed rocks found within a Neoarchean orogen (McGregor and others, 1991; Friend and Nutman, 2005b). The present extent of the IGC is $\sim 3000 \mathrm{~km}^{2}$, and runs obliquely across the coastal fringe, so that in the north it disappears under the Inland Ice in the Isua supracrustal belt area and the most southern exposures are on the Davis Strait coast in the Tre Brødre area (fig. 1).

The later Archean tectonothermal overprints mean that at most localities it is hard to extract any detailed information concerning the early history of the IGC. Fortunately, particularly around the Isua supracrustal belt at the IGC's northern extremity (figs. 1 and 5), there are some domains of lower strain and lower metamorphic grade. This means that individual Eoarchean crustal components can be sampled separately (fig. 4B) and disturbance of whole rock geochemistry and isotopic systems by superimposed events is diminished. Samples from these domains provide the most robust information on the Eoarchean Earth (for example, Baadsgaard and others, 1986a; Bennett and others, 1993, 2003, 2007; Nutman and others, 1996, 1999; Friend and others, 2002; Crowley and others, 2002; Crowley, 2003; Polat and Hofmann, 2003; Hiess and others, 2009; Hoffmann and others, 2010; Nagel and others, 2012).

More than 95 percent of the IGC consists of quartzo-feldspathic rocks, now mostly occurring as strongly deformed orthogneisses. The rare areas of relatively little deformation show that these gneisses usually formed from plutonic tonalite and younger granite (sensu stricto) components (fig. 4B), with lesser amounts of volcanic rocks (Nutman and others, 1996, 1997a, 2011; Bohlar and others, 2004, 2005). All 


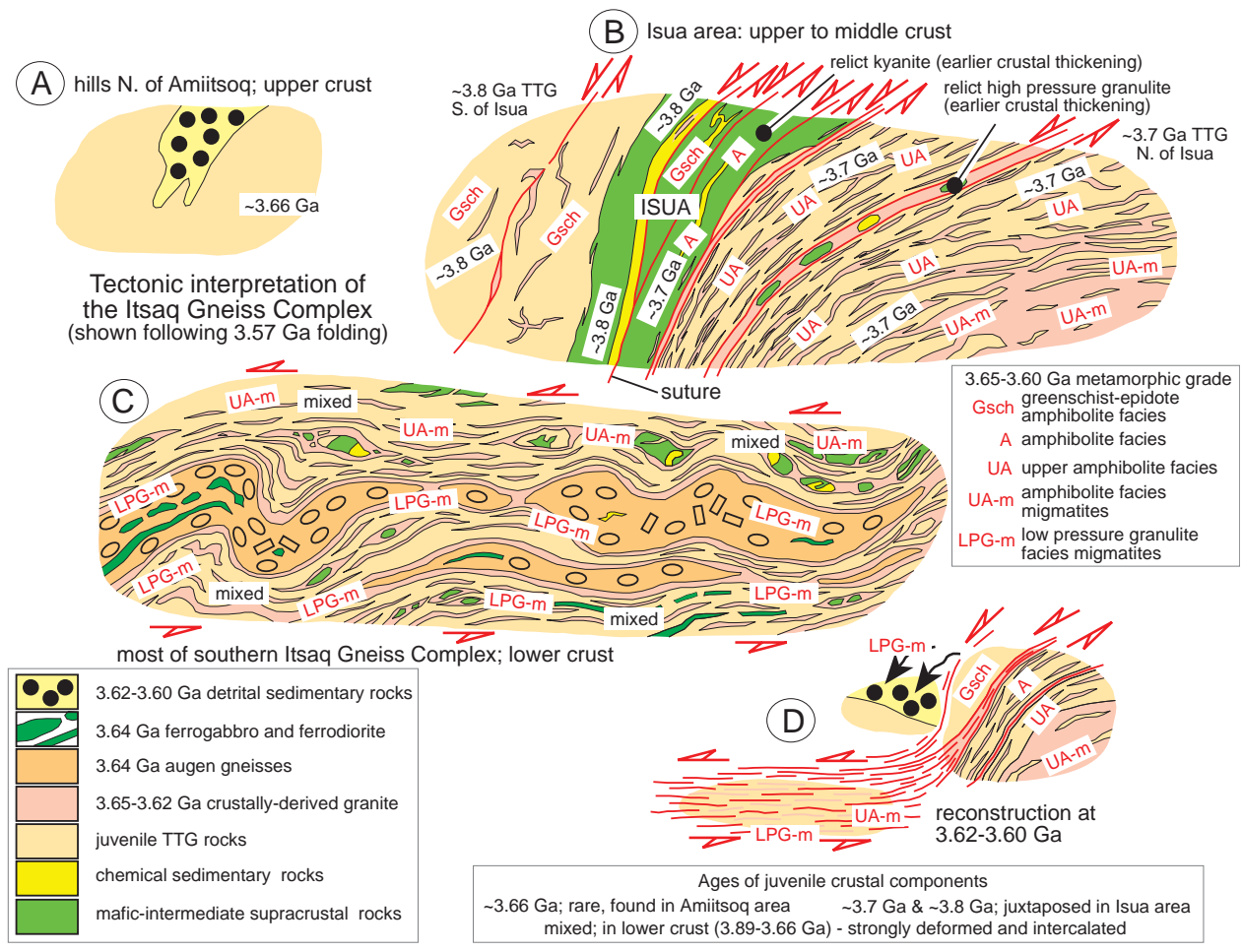

Fig. 3. Schematic cross-sections illustrating state of the Itsaq Gneiss Complex at the end of the Isukasian orogeny. (A) Shows a rare area on the hills north of Amiitsoq (fig. 1) where (meta) detrital sedimentary rocks deposited at 3620-3600 Ma are invaginated with $\sim 3660$ Ma tonalitic basement, and then folded and metamorphosed together at $\sim 3580$ to $3560 \mathrm{Ma}$ (Friend and Nutman, 2005a). This is a rare sample of the upper crust during the Isukasian orogeny. (B) Reconstructs the Isua area, with a schematic cross section through the Isua supracrustal belt. Note the juxtaposition of rocks with different 3650 to $3600 \mathrm{Ma}$ metamorphic grade across extensional structures. (C) Is a schematic representation of the lower crust. 3900 to 3660 Ma juvenile crustal rocks are soaked in 3660 to 3600 Ma neosome. Prevalent metamorphism is upper amphibolite to low-pressure granulite facies. 3640 Ma gabbro-granite composite intrusions show evidence of syn-magmatic extension. (D) is a fusion of A, B and C, to reconstruct the crustal architecture late in the Isukasian orogeny.

researchers (for example, Steenfelt and others, 2005) indicate that the tonalites are compositionally similar to the Archean tonalite-trondhjemite-granodiorite (TTG) suites worldwide. The age of the tonalites ranges from at least $3850 \mathrm{Ma}$ (occurring at several localities) to $3660 \mathrm{Ma}$ in the vicinity of Amiitsoq (fig. 1). The true granites formed largely by partial melting of crust dominated by tonalite (Baadsgaard and others, 1986a; Nutman and Bridgwater, 1986; Hiess and others, 2011).

Volcanic and sedimentary (supracrustal) rocks form $<5$ percent of the IGG and are in tectonic slivers and as enclaves scattered within the more voluminous plutonic rocks. These rocks range in size from the $35-\mathrm{km}$ long Isua supracrustal belt (see Allaart, 1976; Nutman and Friend, 2009), down to sub-meter-sized pods (for example, McGregor and Mason, 1977; Nutman and others, 2002a). They are dominated by banded and meta-volcanic amphibolites that are commonly skarn-bearing, with lesser amounts of quartz-magnetite banded iron formation (BIF), siliceous rocks and marbles. Preservation of original structures and textures is rare. The BIF, siliceous rocks and marbles have together been interpreted as a variegated suite of chemical sediments (Allaart, 1976; Nutman and others, 1984a, 2010; Dymek and Klein, 1988; Dauphas and others, 

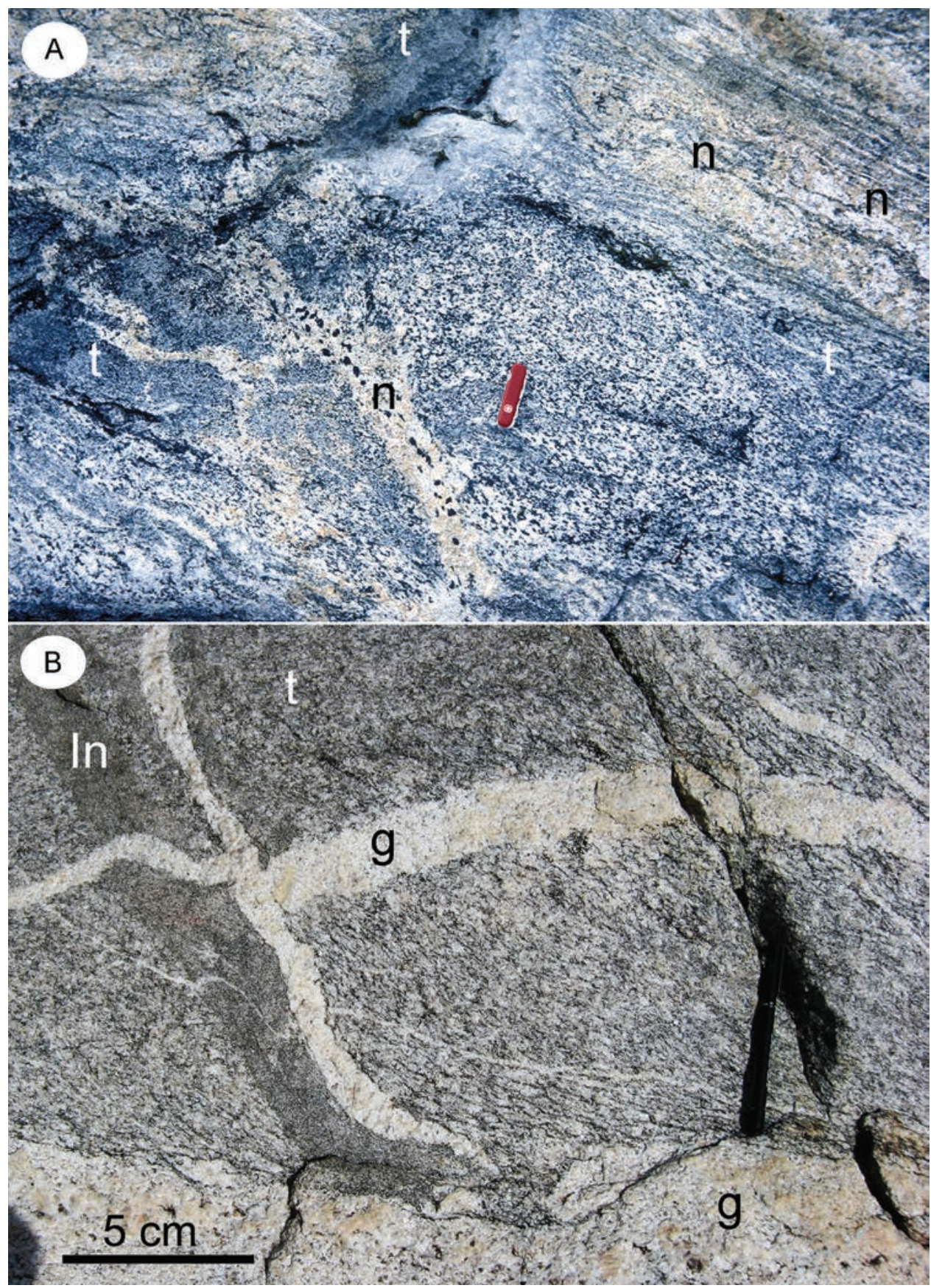

Fig. 4. Orthogneisses of the Itsaq Gneiss Complex. (A) Orthogneiss from the southern part of the Itsaq Gneiss Complex $\left(63^{\circ} 50.920^{\prime} \mathrm{N} 51^{\circ} 39.894^{\prime} \mathrm{W}\right)$ that escaped strong superimposed Neoarchean deformation common in this part of the Complex. Note the variably deformed degree of the neosome (n) across this single outcrop. The tonalitic palaeosome $(\mathrm{t})$ is variably modified by in situ anatexis and disruption by intruded granite and pegmatite veins. The pegmatites with hornblende \pm biotite pseudomorphs replacing original pyroxene are the products of Eoarchean dehydration melting under granulite facies conditions. $\sim 3500$ Ma Ameralik dykes traversing these outcrops (not shown in the frame of view) are weakly deformed and strongly discordant to the migmatite layering. However, they have been converted into amphibolite 

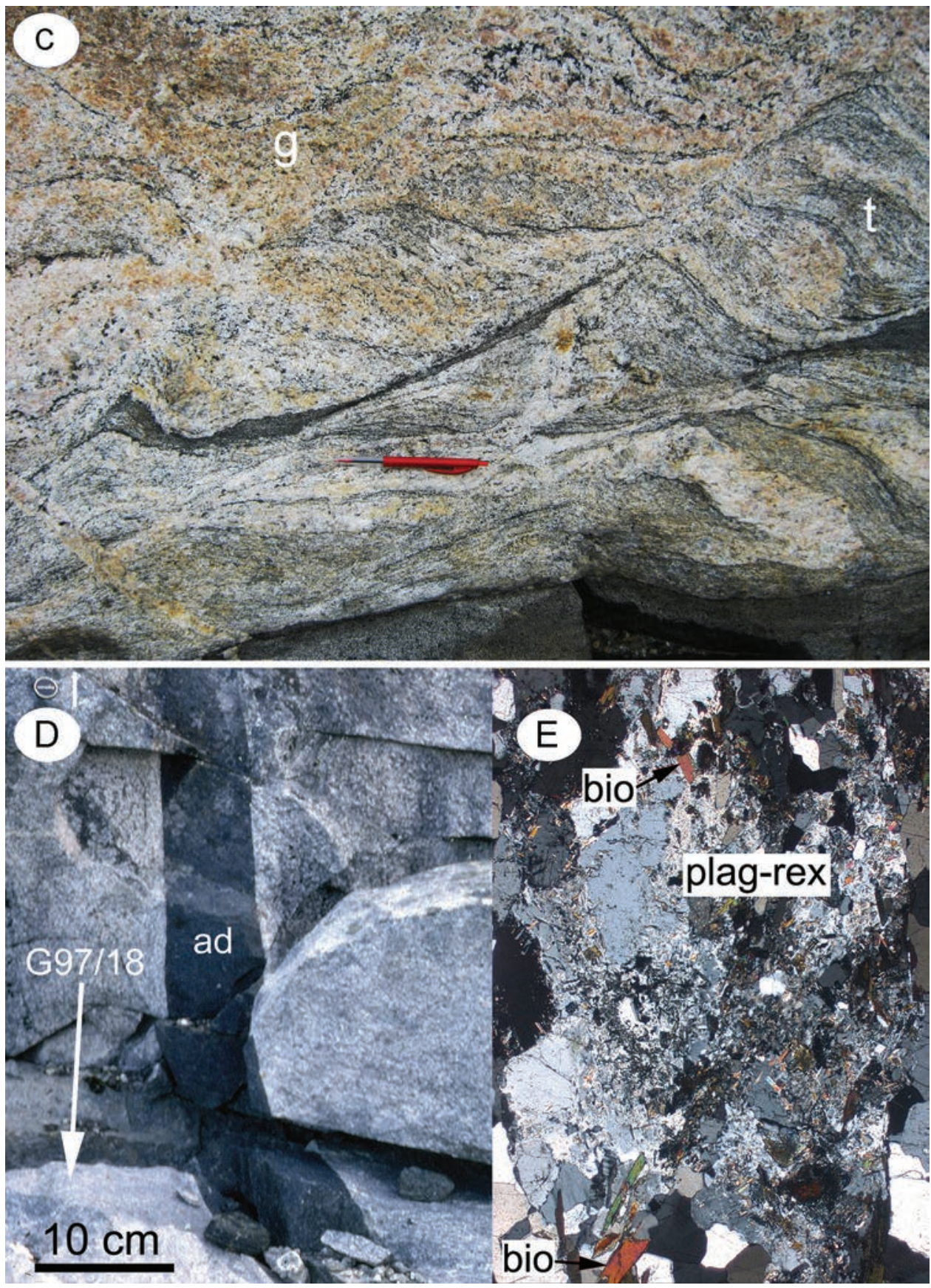

Fig. 4 (continued) during superimposed Neoarchean upper amphibolite facies metamorphism. (B) Low strain zone in the $\sim 3700$ Ma tonalite domain north of the Isua supracrustal belt $\left(65^{\circ} 10.749^{\prime} \mathrm{N}\right.$ $\left.50^{\circ} 01.020^{\prime} \mathrm{W}\right)$. Host $\sim 3700 \mathrm{Ma}$ meta-tonalites (t) are variably deformed, but locally preserve a weakly porphyritic texture, defined by (recrystallized) plagioclase phenocrysts. Note these tonalites are devoid of in situ partial melt domains. They are traversed by a dioritic Inaluk dyke (In) and granite sheets (g). These outcrops are cut by completely non-deformed $\sim 3500$ Ma Ameralik dykes (not shown in the view), which contain relict igneous pyroxenes and plagioclase partially replaced by Neoarchean epidote amphibolite facies assemblages. (C) Early granite $(\mathrm{g})$ in the $\sim 3700$ Ma terrane north of the Isua supracrustal belt 


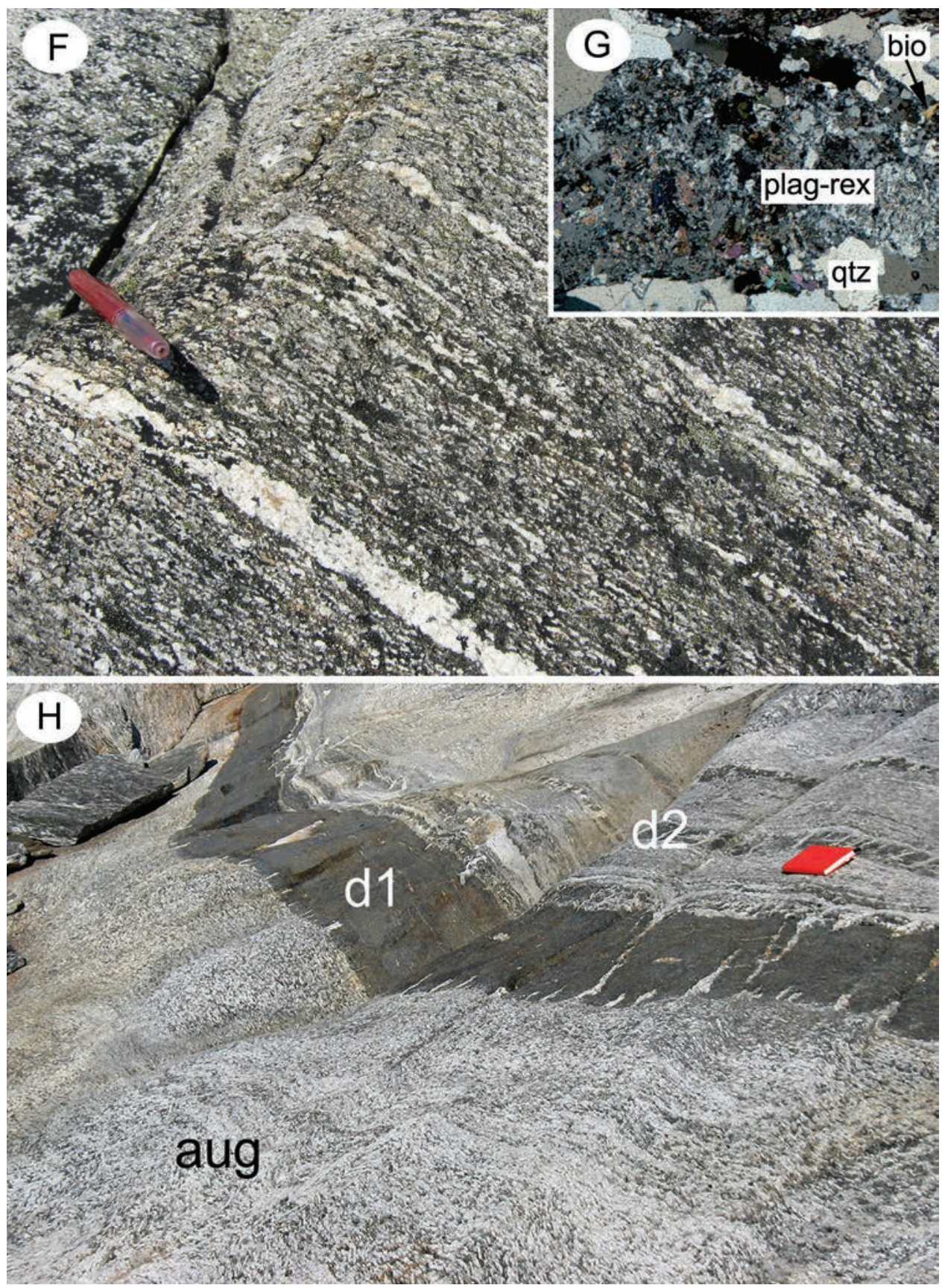

Fig. 4 (continued) $\left(65^{\circ} 10.620^{\prime} \mathrm{N} 50^{\circ} 00.824^{\prime} \mathrm{W}\right)$. Note that these involve at least some in situ anatexis of the host tonalites ( $\mathrm{t}$ ), and the development of synplutonic ductile sigmoidal structures. (D) Homogeneous $\sim 3810 \mathrm{Ma}$ tonalite south of the Isua supracrustal belt $\left(65^{\circ} 00.63^{\prime} \mathrm{N} 50^{\circ} 15.04^{\prime} \mathrm{W}\right.$; sample G97/18). Metatonalite is cut by an amphibolitized but not deformed $\sim 3500 \mathrm{Ma}$ Ameralik dyke (ad). This demonstrates that since the Eoarchean at this locality, there has been no deformation, but superimposed "static" epidote amphibolite facies metamorphism. Preserved in the tonalites is a relict plagioclase-phyric texture. (E) Photomicrograph of G97/18 from the locality shown in (D) demonstrates the early alteration of plagioclase (plag-rex), followed by later static recrystallisation giving randomly orientated laths of biotite (bio) and epidote. (F) Pre- 3500 Ma strong cataclastic deformation affecting 3700 Ma tonalites already intruded by 
2004; Bohlar and others, 2004; Friend and others, 2008; Craddock and Dauphas, 2011). An alternative school of thought regards the carbonates as entirely metasomatic in origin, without sedimentary protoliths (Rosing and others, 1996). Felsic schists and pelites of volcano-sedimentary origin also occur in the Isua supracrustal belt (for example, Nutman and others, 1984a, 1997a, 2011; Bohlar and others, 2005; Kamber and others, 2005). Bodies of metagabbro locally grading into anorthosites are fragments of layered (basic) intrusions, and are spatially associated with layered metaperidotites (Chadwick and Crewe, 1986; Nutman and others, 1996; Friend and others, 2002). Other ultramafic rocks are more magnesian, with very low alumina and lime. They are found largely as metasomatized amphibole \pm phlogopite-bearing schists, within which are rare small pods of non-metasomatized fine-grained dunite and harzburgite. These are interpreted as upper mantle rocks tectonically intercalated with supracrustal rocks, prior to the intrusion of juvenile tonalite suites (Nutman and others, 1996; Friend and others, 2002; Friend and Nutman, 2011).

In and around the Isua supracrustal belt are most of the world's occurrences of Eoarchean rocks preserved in a low strain state. Additionally, the Isua area as a whole has experienced lower grade metamorphism compared with other parts of the IGC (Griffin and others, 1980; Nutman and others, 1996). North of line "N" in figure 5 (see the figure caption for explanation of this line), $\sim 3500$ Ma Ameralik dykes are weakly to un-deformed, showing that Neoarchean deformation is generally low (Bridgwater and McGregor, 1974; Allaart, 1976). These low strain domains also reveal that in situ melting was uncommon at the northern end of the IGC, which greatly aids the interpretation of the early history of these rocks (Nutman and others, 1996).

Much of the rest of the IGC south of line "N" in figure 5 was strongly deformed and highly metamorphosed at both 3660 to $3600 \mathrm{Ma}$ in the Isukasian orogeny and during later Archean tectonothermal events (Nutman, 1984). Nevertheless, there are some domains that escaped both the stronger 3660 to $3600 \mathrm{Ma}$ and later deformation events. These domains provide additional valuable insight into the evolution of the IGC. Thus south of Nuuk in the intersections between the axial regions of Neoarchean recumbent and superimposed upright folds, the 3660 to 3600 Ma characteristics of migmatites are well preserved (fig. 4A). Additionally, within a suite of $\sim 3640 \mathrm{Ma}$ coeval granites and gabbros in the coastal region south of Ameralik (fig. 1) there are domains of low, later Archean deformation with preserved syn-magmatic textures and structures.

\section{The Isua Supracrustal Belt}

Despite the fact the Isua supracrustal belt (fig. 5) largely escaped strong deformation in the Neoarchean, most of it was strongly deformed in the Eoarchean (Nutman and others, 1984a, 1996, 2002b; Myers, 2001). Thus, in most places, primary volcanic and sedimentary structures were obliterated, and outcrop-scale compositional layering is dominantly of transposed tectonic origin. The rare low strain zones indicate that protoliths for most Isua rocks were water-lain, including pillow lavas and breccias (Komiya and others, 1999; Solvang, 1999; Furnes and others, 2007) as well as the chemical sedimentary rocks and also graded felsic detrital rocks derived from volcanic

\footnotetext{
Eoarchean granite sheets $\left(65^{\circ} 09.253^{\prime} \mathrm{N} 50^{\circ} 03.150^{\prime} \mathrm{W}\right)$. The cataclastic textures were recrystallized in superimposed post Ameralik dyke epidote amphibolite facies metamorphism. $(\mathrm{G})$ Cataclastic gneiss showing alteration of plagioclase to albite + epidote + quartz (plag-rex) and the formation of ribbon quartz (qtz). Note the post-kinematic growth of biotite (bio) across the fabric. (H) 3640 Ma augen granite gneisses with coeval mafic intrusions on the south coast of the mouth of Ameralik $\left(64^{\circ} 10.900^{\prime} \mathrm{N} 51^{\circ} 36.395^{\prime} \mathrm{W}\right)$. Augen granite (aug) is intruded by variably attenuated ferrogabbro dikes (notebook for scale). The dike in the middle view (d1) is only mildly attenuated, whereas those in the background (see for example, d2) are disrupted and becoming enclosed and incorporated within the augen granite.
} 


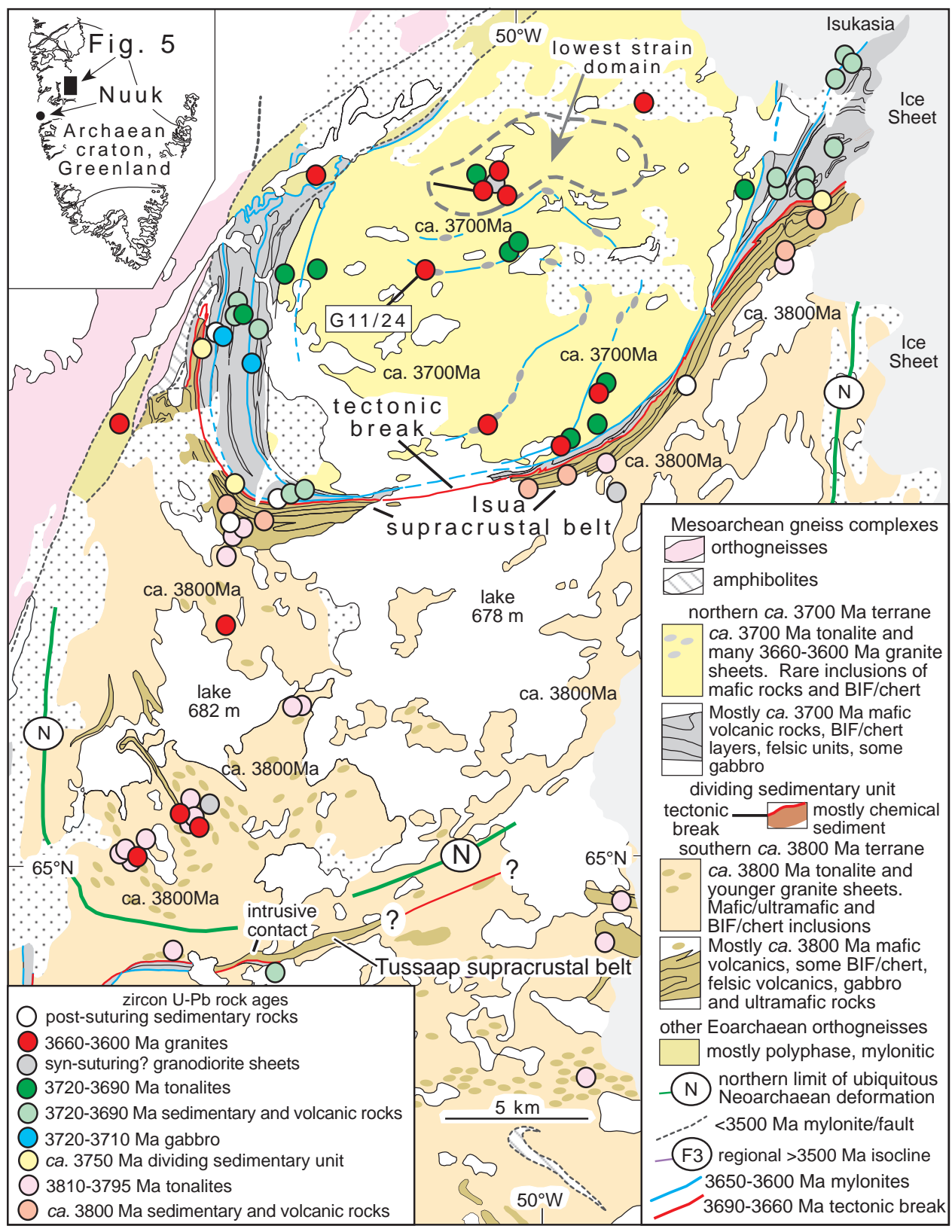

Fig. 5. Map the northern part of the Itsaq Gneiss Complex, covering the Isua supracrustal belt. This is based on revised mapping by Nutman and Friend (2009). Representative zircon age determinations without sample number indicated are by Nutman and co-workers (published). The dating locality with sample number G11/24 is presented in this paper. Line "N" is an approximate boundary between a northern area where post-Ameralik dyke $(<3500 \mathrm{Ma})$ ductile deformation is weak, and a southern area where it is strong. However, to the north there are still some zones of strong late ductile deformation, whereas to the south there are some areas that escaped this later deformation.

sources (Nutman and others, 1984a, 2011). Plutonic rocks are much less common, but include some gabbros and ultramafic rocks derived from both layered gabbro intru- 
sions and the mantle (for example, Dymek and others, 1988; Friend and Nutman, 2011).

The earliest age constraints for the Isua supracrustal belt rocks were provided by $\mathrm{Rb}-\mathrm{Sr}$ whole rock Eoarchean errorchrons (linear scatters of data which give approximate ages with errors of $>50$ million years) for orthogneiss components invading and proximal to the belt (for example, Moorbath and others, 1972, 1977); a whole rock $\mathrm{Pb}-\mathrm{Pb} 3710 \pm 70 \mathrm{Ma}$ errorchron on a BIF (Moorbath and others, 1973); and a Sm-Nd $3770 \pm 42$ Ma errorchron for a mixed suite of felsic and mafic rocks (Hamilton and others, 1978). Within the poor resolution of this early geochronological framework, it was considered that the Isua supracrustal rocks were all related. A subsequent SHRIMP $\mathrm{U}-\mathrm{Pb}$ zircon-dating programme with $\leq \pm 5 \mathrm{Ma}$ uncertainties for rock ages demonstrated that the belt contained supracrustal rocks varying in age by $\sim 100$ million years, with the southern part of the belt dominated by $\sim 3800$ Ma rocks, whereas its northern and central portions contain $\sim 3700$ Ma rocks (figs. 2 and 5; Nutman and others, 1996, 1997a; Crowley, 2003; Kamber and others, 2005). Nutman and others (1997a) first proposed that these unrelated sequences were separated by Eoarchean mylonites and they have expanded on this in more recent work (Nutman and Friend, 2009; Nutman and others, 2009). Despite some adherence to the idea that the belt comprises rocks of the same age (for example, Moorbath, 1994, 2005), most recent workers have now adopted this interpretation (for example, Rizo and others, 2011; Pope and others, 2012).

\section{Detailed Evolution of the 3700 Ma Portion of the Isua Supracrustal Belt}

As the youngest extensive and overall least deformed supracrustal assemblage in the IGC, the $\sim 3700 \mathrm{Ma}$ assemblage along the northern side of the Isua supracrustal belt is the most amenable to provide information on the evolution of Eoarchean volcano-sedimentary sequences (Nutman and others, 2013). The $3700 \mathrm{Ma}$ assemblage comprises tectonically imbricated slices of mostly strongly deformed, amphibolitized pillow lavas and lesser amounts of gabbro (island arc tholeiite, picrite and boninite protoliths; for example, Polat and others, 2002; Polat and Hofmann, 2003), felsic schists (andesite-dacite protoliths; for example, Nutman and others, 1984a, 1997a, 2011; Rosing, 1999; Bohlar and others, 2005), chemical sedimentary rocks (Allaart, 1976; Friend and others, 2008), and depleted mantle dunite (Friend and Nutman, 2011). In a rare low strain area at the northwestern end of the belt $\left(65^{\circ} 08.649^{\prime} \mathrm{N}\right.$ $50^{\circ} 10.488^{\prime} \mathrm{W}$; datum WGS-84), layered gabbro, with amphibolitized relict igneous texture, occurs with boninitic pillow lavas and contains high $\mathrm{Th} / \mathrm{U}$ igneous zircons with an age of $3717 \pm 19 \mathrm{Ma}$ (Nutman and Friend, 2009). Boninitic amphibolites with relict pillow structure are cut by a $3712 \pm 6$ Ma hypabyssal tonalite sheet, and an amphibolite-ultramafic schist tectonic contact is transgressed by a $3717 \pm 6$ Ma mafic tonalite intrusion (Friend and Nutman, 2010). Strongly deformed felsic schists of likely volcanic origin contain 3720 to 3700 Ma igneous zircons, showing they are marginally younger than the intercalated mafic volcanic rocks (Nutman and others, 2009). The 3720 to 3710 Ma rocks are intruded by voluminous, less mafic, $3696 \pm 6$ Ma tonalite. All samples from the $\sim 3700 \mathrm{Ma}$ assemblage have juvenile crustal isotopic signatures, with whole rock initial $\varepsilon_{\mathrm{Nd}}$ values of $\geq+1$ (Baadsgaard and others, 1986a; Jacobsen and Dymek, 1987; data in Moorbath, 2005; Bennett and others, 2007; Hoffmann and others, 2010), and zircon initial $\varepsilon_{\mathrm{Hf}}$ values of $\sim 0$ (Hiess and others, 2009; Kemp and others, 2009; Amelin and others, 2011).

\section{Orthogneiss Complexes Adjacent to the Isua Supracrustal Belt}

The Isua supracrustal belt is bounded to the north by orthogneisses, whose main components are $\sim 3710 \mathrm{Ma}$ (less abundant) and 3700 to $3690 \mathrm{Ma}$ (more common) tonalites, and several suites of 3660 to 3630 Ma granites and pegmatites (Nutman and 
Bridgwater, 1986; Nutman and others, 1996, 2000, 2002b; Crowley and others, 2002). An Eoarchean shear zone (Nutman, 1984; Crowley and others, 2002; Nutman and Friend, 2009; Nutman and others, 1997a, 2002b) separates most of these tonalites from the Isua supracrustal belt (fig. 5). Between 3660 to 3600 Ma the tonalites were invaded by multiple generations of granites and pegmatites (figs. 3B and 4B). These show varying textural and structural relationships with the host tonalites, and new observations on this are presented below, which provide insight into tectonothermal conditions during the 3660 to 3600 Ma Isukasian orogeny.

Although superficially similar in the field, meta-tonalites and their gneissic equivalents on the south side of the Isua supracrustal belt are older than those to the north, with ages of 3820 to 3795 Ma (Nutman and others, 1996, 1999, 2000; Crowley, 2003; Amelin and others, 2011). In the southern 3800 Ma tonalite area there are 3660 to 3630 Ma granitic sheets, but they are less voluminous than granite sheets cutting the tonalites to the north, and tend to be focussed into discrete syn-granite shear zones (fig. 3B).

\section{Tectonic Intercalation Related to Eoarchean Crustal Evolution}

In the Isua supracrustal belt, rocks of different age and origin are tectonically juxtaposed along mylonites that were then folded (Nutman and others, 2002b; Nutman and Friend, 2009). Mylonites within the eastern part of the Isua supracrustal belt and along its northern margin are Eoarchean in age, because dykes that extend across tectonic contacts have U-Pb zircon and baddeleyite ages of $\sim 3500 \mathrm{Ma}$ (White and others, 2000; Nutman and others, 2004a, 2007a; Nutman and Friend, 2009). Further detailed tectonic studies integrated with $\mathrm{U}-\mathrm{Pb}$ zircon dating of the northern $\sim 3700$ Ma portion of the belt have revealed a sequence of intercalation events, starting from $\sim 3710 \mathrm{Ma}$ prior to the completion of juvenile crust formation, through 3690 to 3660 Ma collision with the southern $\sim 3800$ Ma terrane, to 3660 to 3600 Ma postassembly shearing (Crowley and others, 2002; Nutman and Friend, 2009; Friend and Nutman, 2011).

MILESTONES IN UNDERSTANDING THE CRUSTAL DYNAMICS OF THE EOARCHEAN EARTH FROM THE ITSAQ GNEISS COMPLEX

A series of now broadly-accepted findings from the IGC provide robust information on Eoarchean crust formation, lithospheric dynamics and orogeny and include:

\section{Eoarchean Crust Formed in the Archean, and is Not Recycled Hadean Continental Crust}

The first Rb-Sr isotopic studies of IGC orthogneisses of what then were the only-known Eoarchean rocks (Moorbath and others, 1972; Moorbath 1975) recognized that their primitive isotopic signatures (that islow initial ${ }^{87} \mathrm{Sr} /{ }^{86} \mathrm{Sr}$ ) meant they represented predominantly igneous rocks derived from material separated from the mantle only shortly beforehand. Hence they are not material recycled from appreciably older Hadean $(>4000 \mathrm{Ma}$ ) rocks. Numerous isotopic studies using first whole rock $\mathrm{Rb}-\mathrm{Sr}$ and $\mathrm{Pb}-\mathrm{Pb}$, then whole rock $\mathrm{Sm}-\mathrm{Nd}$ (for example, Hamilton and others, 1978; Bennett and others, 1993) and then zircon Lu-Hf (for example, Hiess and others, 2009; Kemp and others, 2009; Amelin and others, 2011; Naerra and others, 2012) have supported this fundamental finding, that is there is no isotopic evidence for the incorporation of earlier Hadean felsic crust in the sources of the IGC orthogneisses.

Studies using whole rock Lu-Hf isotopic compositions of mafic rocks, rather than zircons, from the $\sim 3700 \mathrm{Ma}$ and $\sim 3800 \mathrm{Ma}$ portions of the Isua supracrustal belt further confirm this finding (Hoffmann and others, 2010, 2011b; Rizo and others, 2011). For example, mica schists from the eastern end of the belt whose protoliths were derived from the weathering of mafic volcanic rocks at $\sim 3710 \mathrm{Ma}$ (Nutman and others, 1984a, 1997, 2009) and $\sim 3720$ Ma metabasalts all show a narrow range of near- 


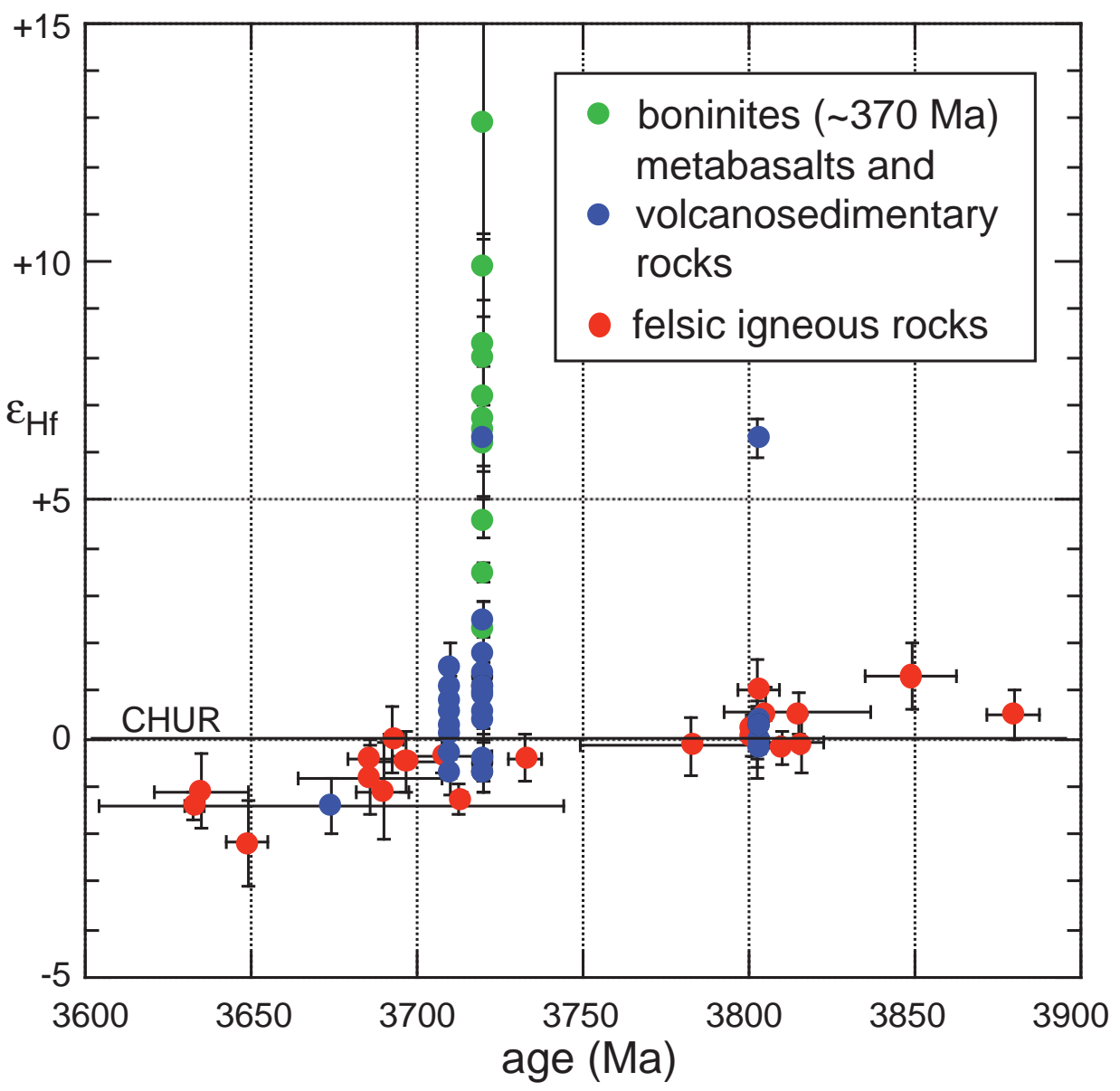

Fig. 6. Summary diagram of initial $\varepsilon_{\mathrm{Hf}}$ values derived from mafic whole rocks and from felsic rocks based on pooled data from their crystallization age zircon populations. For the zircon data from Hiess and others $(2009,2011)$ and Naerra and others $(2012)$, their published weighted mean values were used. For the Kemp and others (2009) and Amelin and others (2011) data, weighted means were calculated from domains whose ${ }^{207} \mathrm{~Pb} /{ }^{206} \mathrm{~Pb}$ age complied with the previously determined protolith age. Mafic whole rock data are from Hoffmann and others (2010, 2011b) and a mafic isochron initial composition from Rizo and others (2011).

chondritic initial $\varepsilon_{\mathrm{Hf}}$ values between +2.5 to -0.7 (fig. 6; Hoffmann and others, 2010, $2011 b)$. This suggests that they were the product of newly-formed mafic rocks, rather than of a weathered Hadean protocrust (as was suggested by Kamber and others, 2005). Likewise, volcano-sedimentary rocks from the western end of the belt (Rosing, 1999 ) with a depositional age of $\sim 3710 \mathrm{Ma}$ (Nutman and others, 2009) fall in the same range of initial $\varepsilon_{\mathrm{Hf}}$ values (fig. 6). An exception to the widespread near-chondritic initial Hf isotopic compositions for mafic whole rocks and zircons for pre-3650 Ma granitoids is seen in a suite of boninitic volcanic rocks (for example, Polat and others, 2002). This boninitic suite, with a likely age of $\sim 3720 \mathrm{Ma}$, has a wide range of initial $\varepsilon_{\mathrm{Hf}}$ values from +1 to $>+10$ (fig. 6). Hoffmann and others (2010) explained this as due to Eoarchean melting of a mantle reservoir that had fractionated Lu-Hf in the Hadean, in order to evolve to the extreme positive $\varepsilon_{\mathrm{Hf}}$ values by $\sim 3720 \mathrm{Ma}$. An alternative explanation offered here is that these rocks represent partial melting of depleted 
upper mantle containing entrained garnet \pm omphacite restite that resulted from early Eoarchean tonalitic crust production. The extremely high $\mathrm{Lu} / \mathrm{Hf}$ of such a source could generate the highly positive $\varepsilon_{\mathrm{Hf}}$ values within $\sim 200$ hundred million years. Partial melting in an olivine + garnet \pm omphacite source would also give rise to the characteristic low $\mathrm{Ca} / \mathrm{Al}$ ratios of these rocks.

Modeling of IGC whole rock $\mathrm{Pb}$ isotopic compositions has been used to estimate the timing of crust separation from the mantle. However, in ancient gneiss complexes such as the IGC, data from the same rocks can be used to reach contrasting conclusions, ranging from large portions of the IGC having formed at $\sim 3650 \mathrm{Ma}$ (Kamber and Moorbath, 1998), to earlier Eoarchean crust formation being important (Tera, 2003), to derivation of some IGC rocks from a Hadean protocrust (Kamber and others, 2003). Difficulties in interpreting these $\mathrm{Pb}$ data arise from the high mobility of $\mathrm{Pb}$ coupled with fraction of $\mathrm{Pb}$ versus $\mathrm{U}$ (expressed as the $\mu$ value; ${ }^{238} \mathrm{U} /{ }^{204} \mathrm{~Pb}$ ) in tectonothermal events affecting the IGC (Baadsgaard and others, 1986b). Thus the Pb isotopic data form highly scattered arrays that intercept possible mantle growth curves between $\sim 3700$ to 3600 Ma (for example, Kamber and Moorbath, 1998; Kamber and others, 2003). Our preferred interpretation of this scattering is Pb-isotopic homogenization of varying efficiency and modification of $\mu$ values during the Isukasian orogeny (McGregor, 2000) and to a lesser degree in younger tectonothermal events. Support for this comes from studies of much younger orogenic systems such as the Paleozoic Lachan orogen of eastern Australia, where plutonic rocks derived from contrasting crustal and mantle sources retain different and original whole rock $\mathrm{Nd}$ isotopic signatures, whereas their $\mathrm{Pb}$ isotopic signatures have been homogenized (McCulloch and Woodhead, 1993). Based on this, and in consideration of increasing uncertainty over appropriate U-Pb isotopic parameters for modelling the early Earth (for example, Albarede, 2009), we are cautious about suggestions based on scattered whole rock Pb isotopic data that IGC rocks were derived from sources with input from Hadean components (Kamber and others, 2003).

Thus using integrated $\mathrm{U}-\mathrm{Pb}$ and $\mathrm{Lu}-\mathrm{Hf}$ data from zircons and whole rock Sm-Nd and Lu-Hf methods there is no compelling evidence within the IGC of Hadean for recycled "continental" crust which would have resulted in strongly negative $\varepsilon_{\mathrm{Hf}, \mathrm{Nd}}$ values by $\sim 3900 \mathrm{Ma}$.

\section{Oceans Before $3700 \mathrm{Ma}$}

Banded iron formation (BIF) is an early Precambrian chemical sedimentary rock that precipitated in a marine environment thus providing evidence of a hydrosphere early in Earth's history. The first $\mathrm{Pb}-\mathrm{Pb}$ whole rock dating at $\geq 3700 \mathrm{Ma}$ of Isua supracrustal belt BIF (Moorbath and others, 1973) showed that the hydrosphere was established very early. This, coupled with the recognition of pillow structures within Isua supracrustal belt basalts (for example, Komiya and others, 1999), means that for surficial processes there was "normality" within Earth's first billion years, such as the hydration and alteration of volcanic rocks. This means that recycling of mafic crust back into the mantle at convergent plate boundaries could promote fluid-flux melting as demonstrated for the melting mechanism producing magmas in modern island arcs (Polat and Hofmann, 2003; Dilek and Polat, 2008).

\section{Complex, Protracted Crustal Evolution from the Study of Meta-Plutonic Rocks}

A bulk dissolution zircon U-Pb geochronological program integrated with whole rock $\mathrm{Nd}$ isotopic analysis on samples of single meta-igneous phases from IGC low strain zones (Baadsgaard and others, 1986a) started to differentiate the age and isotopic signatures of different plutonic protoliths in the IGC. This study was the first to reveal a trend of increasingly less positive to negative initial $\varepsilon_{\mathrm{Nd}}$, with a progression from older juvenile tonalites to younger granites produced by crustal recycling. 


\section{Isotopic Signatures of Multiple Eoarchean Juvenile Crustal Components and Implications for Early Terrestrial Differentiation}

By the mid 1990s, accumulated U-Pb zircon dates by SHRIMP showed that the IGC contains several generations of tonalite suites, from $\geq 3850$ Ma to $\sim 3660$ Ma (Kinny, 1986; Nutman and others, 1993, 1996). Bennett and others (1993) obtained initial $\varepsilon_{\mathrm{Nd}}>+2$ signatures from a sample subset of predominantly less tectonothermallyreworked tonalite samples, showing that they were independent, episodic extractions from a mantle with previous long-term depletion of $\mathrm{Nd}$ relative to $\mathrm{Sm}$. Both these findings have now been reproduced and accepted (for example, Crowley and others, 2002 and Crowley, 2003 for the zircon dating, and Caro and others, 2006 for the whole rock Nd work). Further evidence for the juvenile nature of the tonalitic orthogneisses comes from the mantle-like ${ }^{18} \mathrm{O} /{ }^{16} \mathrm{O}$ isotopic compositions of their zircons as demonstrated by Hiess and others (2009) in the first in situ oxygen isotopic study of zircons from the IGC.

\section{Eoarchean Juvenile Crustal Igneous Rocks Have Geochemical Signatures Resembling Ones Formed at Younger Convergent Plate Boundaries}

Whole rock geochemical studies of non-migmatized tonalites showed they are predominantly products of partial melting of eclogitized mafic rocks (Nutman and others, 1999). Although the melting of mafic rocks at high pressure is the widely accepted source for these rocks, detailed trace element studies by Hoffmann and others (2011a) suggested that melting at lower pressures (high pressure granulite assemblages?) is feasible for some compositions. Furthermore, the composition of the source is debated. Nutman and others (1999) suggested that a MORB-like source could be dominant, whereas Nagel and others (2012) suggested it is more likely that the source was akin to Isua arc-like basalts. However, in our opinion, this issue is clouded by the compositions used in modeling by Nagel and others (2012) not being the best representatives of Isua arc-like basalts. Clearly, further studies are required to investigate the likely source compositions, and how they might have changed with time as the Eoarchean arc-like assemblages evolved.

The mafic and intermediate rocks associated with the tonalites display signatures showing domination of upper mantle sources that melted due to fluxing from fluids released from a "subducted" slab (for example, Polat and Hofmann, 2003; Jenner and others, 2009). More detailed examination of the trace element geochemistry of Isua mafic rocks indicates that although this mechanism is dominant, there may also be a contribution from slab melts (Hoffmann and others, 2011b). Combined with the juvenile isotopic signatures of these rocks, this suggests that IGC Eoarchean crust formed at convergent plate boundaries, in an environment with some resemblance to modern intra-oceanic arc settings (see summary by Dilek and Polat, 2008).

\section{Eoarchean Assembly of Unrelated Juvenile Crust Domains}

Integrated structural and zircon U-Pb dating studies demonstrate that juvenile components of the IGC evolved separately, prior to assembly and a 3660 to $3600 \mathrm{Ma}$ orogeny (Nutman and others, 1993, 1996). The most detailed information on this comes from the Isua supracrustal belt environs, where it is demonstrated that by 3660 Ma a juvenile northern composite $\sim 3700$ Ma arc-like assemblage was juxtaposed against an older complex dominated by $\sim 3800$ Ma rocks, also likely the product of an arc system (figs. 3B and 5; Nutman and others, 1996, 2009; Crowley, 2003; Jenner and others, 2009; Nutman and Friend, 2009). These findings indicate that lateral lithospheric movements resulting from upper mantle convection were occurring in the Eoarchean, with the further implication that upper mantle convection was an available and likely important heat-loss mechanism for the early Earth. 


\section{Differentiation of the Mantle Reservoir that Spawned Itsaq Gneiss Complex Juvenile Crust}

Increasing integration of accurate and precise U-Pb zircon dating with whole rock ${ }^{143} \mathrm{Nd}$ and ${ }^{142} \mathrm{Nd}$, zircon $\mathrm{Hf}$ and whole rock W isotopic signatures are refining the timing and nature of fundamental terrestrial differentiation to events within the first 60 million years of Earth history (for example, Caro and others, 2006; Bennett and others, 2007; Hiess and others, 2009; Willbold and others, 2011; Rizo and others, 2011). Furthermore, they reveal that although these events strongly fractionated Sm and $\mathrm{Nd}$ in the upper mantle reservoir, they did not fractionate Lu from Hf to the same degree. This gives rise to the characteristic initial whole rock $\varepsilon_{\mathrm{Nd}}$ of +4 to +2 , positive ${ }^{142} \mathrm{Nd}$ isotopic anomalies of $>+10$ p.p.m. compared to modern rocks and zircon $\varepsilon_{\mathrm{Hf}}$ of +1 to 0 for Eoarchean juvenile crust (fig. 6; Bennett and others, 1993, 2007; Hiess and others, 2009; Kemp and others, 2009; Amelin and others, 2011).

COMPLETE SHRIMP ZIRCON U-Pb GEOCHRONOLOGICAL SURVEY: SNAPSHOT OF ITSAQ GNEISS COMPLEX EARLY GRUSTAL EVOLUTION

Starting from 1986, zircons from 160 IGC meta-igneous samples have now been dated by the SHRIMP U-Pb technique. Compston and others (1986) demonstrated (with then unsurpassed precision and accuracy) that felsic schists along the southern margin of the Isua supracrustal belt have an age of $3806 \pm 2 \mathrm{Ma}$. In retrospect, the lack of younger overgrowths on these zircons suggests that superimposed metamorphic events were mild at this locality. Kinny (1986) obtained an older protolith age of $3822 \pm 10 \mathrm{Ma}$ for a tonalitic gneiss south of Nuuk (sample 110999; fig. 1), with metamorphic overgrowths dated at $\sim 3630 \mathrm{Ma}$. Combined with the $\sim 3700$ Ma bulk zircon ages for other tonalites published in the same year (Baadsgaard and others, 1986a), these initial studies showed that rocks of considerably different age are present in the complex, and that high temperature metamorphic overprint was variable and could be dated accurately. Broader geochronological appraisals published by Nutman and others $(1993,1996)$ expanded upon this, and they presented data to demonstrate that the IGC's rock record extended to $>3850 \mathrm{Ma}$, that is, significantly older than rocks in the Isua supracrustal belt. Furthermore, these studies demonstrated that even the oldest ( $\geq 3800 \mathrm{Ma}$ ) tonalite components did not start to develop significant zircon metamorphic overgrowths until 3650 to $3600 \mathrm{Ma}$, which gave rise to a model of accumulation of juvenile crustal assemblages prior to $\sim 3650 \mathrm{Ma}$ without significant regional metamorphism, followed by 3650 to $3600 \mathrm{Ma}$ high temperature orogeny (Nutman and others, 1993). The lesser amount of ID-TIMS zircon U-Pb dating has confirmed the diverse ages for rocks in the IGC (for example, Crowley and others, 2002; Crowley, 2003; Amelin and others, 2011).

Since 2004 there has been a program of reconnaissance dating of $>100$ samples using the Hiroshima University SHRIMP (for example, Horie and others, 2010). This program has been completed, with dating now covering the whole IGC, albeit with varying density. In this reconnaissance programme, typically $\sim 10$ cathodoluminescenceguided analyses were undertaken per sample, in order to fill-in geographic areas of considerable extent previously devoid of any age determinations. Extra analyses were undertaken only when "interesting" samples were revealed in the reconnaissance. Most significant of these was the discovery of a mildly migmatized $3891 \pm 6$ Ma tonalite in the southeastern part of the IGC (sample G01/36 on fig. 1; Hiess and others, 2009; Horie and others, 2010).

THE 3660 TO 3600 Ma ISUKASIAN OROGENY

The IGC contains contrasting crustal levels juxtaposed during a 3660 to $3600 \mathrm{Ma}$ orogeny (fig. 3; Griffin and others, 1980; Nutman and others, 1996; Friend and Nutman, 2005a). This orogeny is named here the Isukasian, after the geographic region Isukasia at the northern end of the Itsaq Gneiss Complex where effects of this 
orogeny are least modified by superimposed Neoarchean orogenic events. However, new structural and textural observations presented here provide further insight into crustal response during this event and help suggest its cause.

\section{Anatomy of Deep Crustal Migmatites}

The rare domains of lower strain in the IGC south of line "N" (fig. 5) show that the juvenile tonalitic protoliths are only locally well preserved (Nutman and others, 2000, 2007a, 2007b). As a generality, these tonalites were reduced to palaeosome in complex migmatites, whose granitic neosome was derived both from in situ anatexis of the tonalites and from intrusions (fig. 4A). These anatectic and intrusive events have been equated with petrographic evidence for high grade Eoarchean metamorphism up to granulite facies (McGregor and Mason, 1977; Griffin and others, 1980; Friend and Nutman 2005a).

These migmatites were generally converted into banded gneisses by superimposed younger Archean deformation, to such an extent, that they can be "laundered" into superficially homogeneous rocks (Nutman and others, 2000, 2004b; Horie and others, 2010). However, the tracing of these banded gneisses into small low strain zones demonstrates their complex early history with several different igneous phases present. This is not a trivial observation, because it resolves divergent interpretations of these gneisses that are possible, if based solely on in situ zircon U-Pb zircon geochronology, without taking geological field observations into account. Thus taking these gneisses superficially as single igneous phases, Whitehouse and others (1999) interpreted them as $\sim 3650$ Ma rocks that carried abundant older inherited zircons, whereas using field observations, Nutman and others $(1996,2000)$ interpreted them as polyphase samples with Eoarchean igneous components differing in age by as much as 200 million years. Such a divergence of opinion upon the age of rocks has major ramifications concerning the initial whole rock isotopic signatures of these rocks and thereby the severity of fractionation in the earliest upper mantle reservoirs (Bennett and others, 2007).

Where least modified by superimposed post-Ameralik dyke (that is $\sim 3500 \mathrm{Ma}$ ) deformation, the deep crustal migmatites have a broadly planar fabric that Ameralik dykes always cut at a high angle. Evidence of this angular relationship is widespread in the area of very low post-3500 Ma strain north of the Isua supracrustal belt (fig. 5), where pre-3500 Ma tectonic fabrics are gently inclined but are cut by un-deformed sub-vertical Ameralik dykes. Thus with the reasonable assumption that the majority of dikes were originally steeply inclined, this would permit that the migmatitic structures were originally sub-horizontal. Moreover, upon the same outcrop, the least modified migmatites show varying degrees of strain in the neosome (fig. 4A). This is best explained by heterogeneous pre-3500 Ma ductile deformation, with in situ neosome production and injection coeval with ductile deformation. The proposed originally sub-horizontal nature of migmatite banding is best accommodated in deep crustal lateral flow (Sandiford, 1989), and the presence of anatectic melt between $\sim 3660$ to $3600 \mathrm{Ma}$ associated with punctuated thermal maxima at $3642 \pm 16,3621 \pm 8,3599 \pm 6 \mathrm{Ma}$ as recorded by zircon growth in migmatites on Akilia island (Friend and Nutman, 2005a) would have greatly enhanced strain (Hollister and Crawford, 1986). Thus we propose that these migmatites lay testament to extreme strain with melt-lubricated lateral flow of the deep crust over a period of $\sim 50$ million years.

Units of 3640 to $3635 \mathrm{Ma}$ (Baadsgaard, 1973; Nutman and others, 2000; Hiess and others, 2011) Fe-rich augen granites, monzonites and ferrogabbros are a distinct component of the part of the IGC south of Ameralik (fig. 1; McGregor, 1973). These are the product of hybridization of fractionated magmas derived from the mantle and anatexis of the deep crust, and consequently resemble A-type/within-plate-granites with high $\mathrm{Nb}, \mathrm{Zr}, \mathrm{TiO}_{2}$ and $\mathrm{P}_{2} \mathrm{O}_{5}$ (Nutman and others, 1984b, 1996). These rocks, like 
their host neosome-soaked migmatites, allay to an elevated geothermal gradient in the deep crust being linked at least in part by the emplacement of mantle-derived melts.

\section{0 to 3600 Ma Structures and Granite Emplacement in 3800 Ma Tonalites South of the Isua Supracrustal Belt}

South of the Isua supracrustal belt (fig. 5) all Ameralik dykes carry metamorphic hornblende, and locally garnet. Thus, the 3800 Ma rocks were overprinted by Neoarchean lower to middle amphibolite facies metamorphism (Nutman and others, 1996). This is also demonstrated by 2700 to $2600 \mathrm{Ma} \mathrm{U}-\mathrm{Pb}$ titanite ages from these 3800 Ma rocks (Crowley, 2003) and a $\sim 2690 \mathrm{Ma}$ U-Pb monazite age on an Eoarchean pegmatite (Nutman and others, 2002b). The tonalites south of the Isua supracrustal belt contain rare areas of very low total strain (fig. 4D), with preservation of weakly plagioclase-phyric igneous textures (Nutman and others, 1999). However, even these rocks with the lowest superimposed strain have been thoroughly recrystallized, and no igneous phases are preserved, apart from zircon. Thus even where there is a plagioclasephyric texture, the igneous plagioclase phenocrysts have been pseudomorphed by subgrain mosaics (fig. 4E), which finally recrystallized during superimposed Neoarchean amphibolite facies metamorphism. Another feature of the $\sim 3800$ Ma terrane for at least $10 \mathrm{~km}$ south of the Isua supracrustal belt is the lack of pre-Ameralik dyke (>3500 Ma) in situ anatexis within the tonalites and although 3660 to 3600 Ma granites occur, they are volumetrically less than to the north of the belt (Nutman and others, 1999; Crowley, 2003). These form discrete intrusions, with a tendency to have been emplaced in and around active shear zones (Friend and others, 2002; Nutman and others, 2002b). The $\sim 3800 \mathrm{Ma}$ tonalites may display a pre-Ameralik dyke cataclastic texture, albeit this has been recrystallized during superimposed Neoarchean amphibolite facies metamorphism. The possible presence of such a texture, the lack of in situ anatexis and the focussing of 3660 to 3600 Ma granitic intrusions along active shear zones rather than being distributed through migmatites all suggest that at 3660 to 3600 $\mathrm{Ma}$, the $\sim 3800 \mathrm{Ma}$ domain on the south side of the Isua supracrustal belt was at a higher, cooler crustal level than the migmatites that are prevalent in the southern exposures of the IGC. Exact conditions are yet to be resolved, but the presence of pre-Ameralik dyke cataclastic textures would suggest sub-amphibolite facies conditions.

3660 to 3600 Ma Structures, Fabrics and Granite Emplacement in 3700 Ma Tonalites North of the Isua Supracrustal Belt

North of the Isua supracrustal belt, $\sim 3700$ Ma tonalites display a range of relationships with several generations of 3660 to 3600 Ma granites, and there was ductile to brittle fabric development prior to intrusion of the Ameralik dykes. Crowley and others (2002) presented field observations integrated with U-Pb zircon and titanite geochronology of two localities to provide more detailed insight into the early tectonic history. They demonstrated (i) that the host tonalites ranged from undeformed to foliated (S1) and were folded prior to intrusion of the oldest granites, (ii) that the Inaluk dykes (a composite suite of mafic diorite and co-magmatic granitic pegmatite; Nutman and Bridgwater, 1986) were intruded at $3659 \pm 2 \mathrm{Ma}$, prior to (iii) intrusion of more voluminous granite sheets at $3644 \pm 3 \mathrm{Ma}$, which they regarded as synchronous with the development of a second fabric (S2). Close to the Isua supracrustal belt they recognized further deformation of the tonalites and granite sheets to give a third foliation (S3).

In this paper we contribute new information on the relationships between successive generations of granite and pegmatite intrusions and the tectonothermal evolution. In the north-central part of this area, relationships between the tonalites and granites are least-modified by superimposed, but still pre-Ameralik dyke, deforma- 
tion (Nutman and Bridgwater, 1986; this area is indicated as "lowest strain domain" in fig. 5). These rocks are overall "fresh" with widespread preservation of igneous textures (fig. 4B), and the tonalites locally have relicts of igneous plagioclase in phenocrysts, and granites and pegmatites contain fresh alkali feldspar and relict igneous plagioclase. The tonalites were intruded by the $3659 \pm 2$ Ma Inaluk dykes (fig. 4B; Crowley and others, 2002), prior to local in situ anatexis of the tonalites with production of the earliest granites (fig. 4C). Paleosome schlieren in these early granites are ductilelydeformed into sigmoidal shapes, indicative of syn-magmatic extensional deformation (fig. 4C). The schlieric granites are cut by better-defined granite sheets that occupy fracture networks whose geometry also indicates extensional deformation. These are equated with the granites in the same area dated at $3649 \pm 6$ Ma by Nutman and others (2000) and $3644 \pm 3 \mathrm{Ma}$ by Crowley and others (2002).

In an amphibolite pod within a belt of pegmatite with widely developed flaser texture (sample locality G11/24 in fig. 5) we have discovered a lower strain zone with the relict high-pressure granulite facies assemblage garnet + clinopyroxene + hornblende + plagioclase + quartz (fig. 7A). Dehydration partial melting is the likely process because exterior to the segregations the amphibolites do not contain garnet and clinopyroxene. Consequently, this assemblage is considered to have formed with garnet + clinopyroxene \pm hornblende in equilibrium with a trondhjemitic melt (crystallized as plagioclase + quartz). Zoned magmatic zircons in this partial melt segregation (sample G11/24) have been dated by the SHRIMP U-Pb method (Appendix 1). Small equant and prismatic zircons are oscillatory-zoned, with partial recrystallization to give homogeneous or sector-zoned domains (fig. 7B). In both varieties $U$ and $\mathrm{Th} / \mathrm{U}$ are generally low (mostly $<100 \mathrm{ppm}$ and always $<0.01$, respectively). Most analyses yield close to concordant U-Pb ages, with ${ }^{207} \mathrm{~Pb} /{ }^{206} \mathrm{~Pb}$ ages mostly between 3700 and $3550 \mathrm{Ma}$ (fig. 7C; Appendix 1). In some cases distinctions between genuine oscillatory zoned igneous zircon and various types of recrystallized zircon is very subtle. If there was any doubt that the analytical sites were composite (containing both igneous + recrystallization domains) they were not used in age assessments. Using this conservative approach, $3658 \pm 3$ Ma was obtained for the oscillatory-zoned zircon, and $3635 \pm 2 \mathrm{Ma}$ and $3591 \pm 5 \mathrm{Ma}$ (all 95\% confidence and MSWD $\leq 1.0$ ) for successive generations of recrystallized zircon. Some other sites of recrystallization occur in the centers of grains, are bright in CL images and have lost $\mathrm{U}$ and Th (fig. 7B). Some of these sites have markedly reverse discordant ages, coupled with older ${ }^{207} \mathrm{~Pb} /{ }^{206} \mathrm{~Pb}$ ages, suggesting non-supported radiogenic $\mathrm{Pb} .3658 \pm 3 \mathrm{Ma}$ is indistinguishable from the Crowley and others (2002) $3659 \pm 2 \mathrm{Ma}$ age obtained on the Inaluk dykes, the first event common to both the northern $\sim 3700 \mathrm{Ma}$ and southern $\sim 3800 \mathrm{Ma}$ terranes. This ties the elevated pressure event to the start of the common history between the two terranes. Reconstruction of the pressure-temperature-time history of this sample will be reported elsewhere, but preliminary estimates indicate pressures of $\geq 1 \mathrm{GPa}$. The zircon crystalllization age of sample G11/24 zircon recrystallization age of $3635 \pm 2$ Ma agrees with the age of $3633 \pm 5$ obtained on a flaser pegmatite strand in the central gneisses (Nutman and others, 2002b). The $3591 \pm 5$ Ma age also agrees with zircon recrystallization ages previously obtained from the Isua area (Nutman and others, 2002b).

Away from the area of "freshest" rocks indicated as "lowest strain domain" in figure 5, both the tonalites and cross-cutting granites have been variably and locally strongly deformed prior to intrusion of the Ameralik dykes (Nutman, 1984; Crowley and others, 2002). This has locally reduced the granite sheets to subconcordant layers within their tonalite host. Well north of the Isua supracrustal belt, in areas devoid of post-Ameralik dyke strain (that is, the dikes are close to vertical and non-deformed), cataclastic texture is preserved within such rocks (fig. $4 \mathrm{~F}$ ), with kinematic indicators 

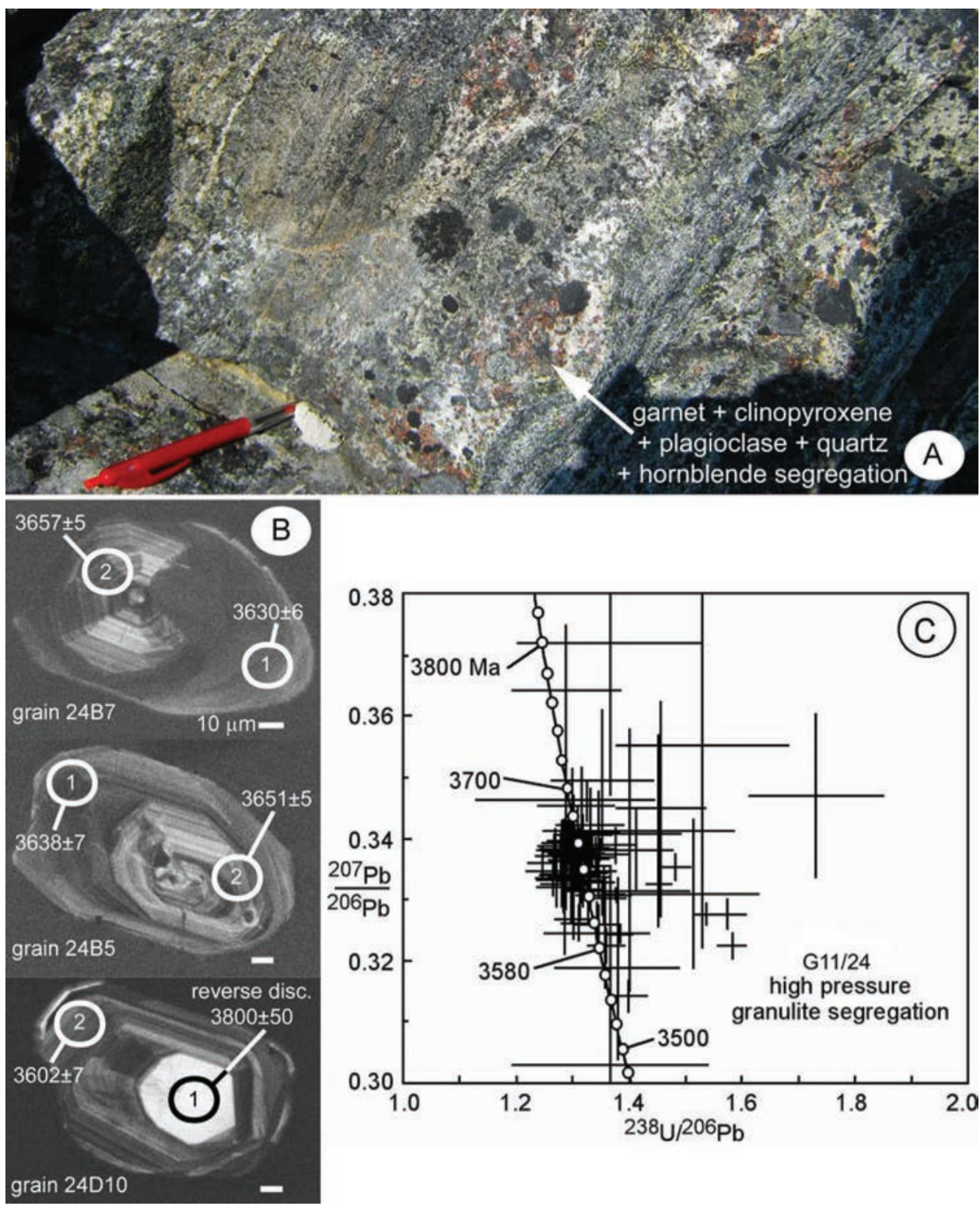

Fig. 7. (A) Garnet + clinopyroxene + hornblende + plagioclase + quartz segregations within banded amphibolites (GPS $65^{\circ} 09.087^{\prime} \mathrm{N} 50^{\circ} 03.619^{\prime} \mathrm{W}$ ), probably formed by dehydration partial melting. (B) CL images of representative zircons from segregation sample G11/24. Scale bar in all frames is $10 \mu \mathrm{m}$. Analytical errors on the ${ }^{207} \mathrm{~Pb} /{ }^{206} \mathrm{~Pb}$ ages are given at the $1 \sigma$ level. $(\mathrm{C}){ }^{238} \mathrm{U} /{ }^{206} \mathrm{~Pb}-{ }^{207} \mathrm{~Pb} /{ }^{206} \mathrm{~Pb}$ concordia diagram summarizing SHRIMP U-Pb zircon dating from partial melt segregation G11/24. Analytical errors are depicted at the $2 \sigma$ level, and the results are presented in Appendix 1 . A few strongly discordant analyses are outside of the range of this plot.

indicating extensional deformation. This pre-Ameralik dyke cataclastic texture indicates Eoarchean deformation at the ductile-brittle transition, under sub-amphibolite facies conditions. Micro-fabrics related to this are indicated in figure $4 \mathrm{G}$, with ribbon quartz and the degradation of plagioclase into altered subgrains defining the $\mathrm{S}$ fabric. 
Note that fine-grained biotite grains are randomly orientated across this fabric, having grown during superimposed "static" Neoarchean epidote-amphibolite facies metamorphism. The development of the cataclastic textures is synchronous with, or predates, the intrusion of strands of syn-kinematic 3640 to 3630 Ma flaser-textured pegmatite. The strands of flaser-textured pegmatite are continuous for many kilometres and contain trains of ultramafic, amphibolite and siliceous inclusions. These inclusions are probably dismembered supracrustal rocks, and seem largely restricted to the shear zones occupied by the pegmatites (Nutman, 1984; Nutman and Friend, 2009).

Thus the gneiss complex north of the Isua supracrustal belt shows a $3650 \mathrm{Ma}$ to $\sim 3630 \mathrm{Ma}$ record of repeated granite emplacement that started at deeper high temperature domains with the development of schlieric migmatites (fig. 4C) following on from transient high-pressure metamorphism (sample G11/24), through the emplacement of granites as sheets occupying fractures (but where ductile deformation could be sustained at lower strain rates), to emplacement synchronous or post-dating sub-amphibolite facies cataclasis (fig. $4 \mathrm{~F}$ ). In all cases there are structural indications of extensional deformation. Extension over the course of $\geq 10$ million years gave rise to tectonic thinning of the crust, and might be responsible for elevating the host rocks from the fringes of the ductile anatectic zone $\left(\geq 650{ }^{\circ} \mathrm{C}\right.$ ? $)$ to cataclastic subamphibolite facies conditions $\left(<500^{\circ} \mathrm{C}\right)$. This can explain the telescoping of early metamorphic conditions in the Isua area from greenschist/epidote amphibolite facies to upper amphibolite facies migmatites, with "jumps" of early metamorphic grade across Eoarchean shear zones (fig. 3B).

\section{0 to 3600 Ma Shear Zones}

In the Isua area, the juvenile crustal components are partitioned by pre-Ameralik dyke (>3500 Ma) shear zones (Nutman, 1984; Nutman and Friend, 2009). One of these shear zones defines the eastern-central margin of the Isua supracrustal belt, but westwards cuts into the belt (fig. 5; Nutman and Friend, 2009). This shear zone post-dates $3649 \pm 4$ Ma granite sheets (Crowley and others, 2002). At the margin of the Isua supracrustal belt this shear zone is commonly occupied by syn-kinematic flasertextured pegmatite (Nutman, 1984). Constraining the age of shear zones south of the belt are U-Pb zircon $3645 \pm 7 \mathrm{Ma}$ and $3607 \pm 5 \mathrm{Ma}$ ages for pre- and post-mylonite granite sheets (Friend and others, 2002; Nutman and others, 2002b) and for north of the belt a $3633 \pm 7$ Ma syn-mylonite pegmatite (Nutman and others, 2002b).

\section{DISCUSSION}

\section{Mosaic of Ages Across the Itsaq Gneiss Complex}

There is a mosaic of different "families" of tonalite protolith ages with each "family" containing two or more "generations" (fig. 2). The youngest at $\sim 3660 \mathrm{Ma}$ (Friend and Nutman, 2005a) forms a limited $<5 \mathrm{~km}$ broad domain around Amiitsoq (McGregor's type locality for the Amîtsoq gneisses; fig. 1). These are devoid of the strong Eoarchean tectonothermal overprint; anatexis is only seen in older Eoarchean rocks flanking both sides of the Amiitsoq domain, with which they appear to be tectonically juxtaposed (Friend and Nutman, 2005a). Tonalites with ages of $\sim 3800 \mathrm{Ma}$ form another family, which comprises 3820 to 3805 and 3795 to 3790 Ma generations. South of the Isua supracrustal belt to beyond line "N" these form a uniform assemblage, apparently devoid of older components (fig. 5; Nutman and others, 1999, 2002b; Crowley, 2003). On Akilia and several surrounding islands, at the northern edge of the Mesoarchean Ivisaartoq supracrustal belt, and in the southeastern part of the IGC in Itilleq (fig. 1), a 3890 to 3840 Ma tonalite family has been detected (Nutman and others, 1996, 1997b, 2000, 2002a, 2007b; Hiess and others, 2009; Horie and others, 2010). Commonly associated with them are $\sim 3760$ Ma tonalites. Local low strain zones 
preserve evidence that the $\geq 3840$ Ma rocks were intruded by $\sim 3760$ Ma tonalites (Nutman and others, 2000), but the relationships with nearby $\sim 3800$ Ma rocks is presently unknown. The $\sim 3700 \mathrm{Ma}$ tonalite family (with $3715-3710$ and $3700-3685 \mathrm{Ma}$ generations) is best preserved to the north of the Isua supracrustal belt, where they are found in tectonic contact with $\sim 3800$ Ma rocks to the south (fig. 5). Migmatized $\sim 3700 \mathrm{Ma}$ tonalites form other parts of the IGC. For example at the southeastern edge of the IGC in Itilleq and Ameralla (fig. 1), migmatites with $\sim 3700$ Ma paleosome appear to be mutually exclusive from domains with $\geq 3800$ Ma paleosome (Horie and others, 2010). Thus despite the strong superimposed Neoarchean deformation in this part of the IGC, it is possible that different $\sim 3700 \mathrm{Ma}$ and $\geq 3800 \mathrm{Ma}$ tonalitic units were also tectonically assembled, prior to a common 3660 to 3600 Ma migmatization event.

The accrued dating program also permits oversight on the extent of 3660 to 3600 Ma new zircon overgrowths in the juvenile tonalites. In a broad fashion, this is a proxy of 3660 to 3600 Ma high metamorphic temperatures. This is a valid assumption, because in the migmatites in the south of the complex, zircons were most modified at 3660 to $3600 \mathrm{Ma}$, the rocks are most intensely migmatized, and they preserve local relicts of Eoarchean granulite facies metamorphism (Nutman and others, 2000, 2002a; Friend and Nutman, 2005a). The widespread occurrence of 3660 to 3600 Ma overgrowths indicates that much of the IGC was affected by high temperatures at that time, with the significant exception being parts of northern end of the IGC around the Isua supracrustal belt, and other small (tectonically bounded?) domains such as around Amiitsoq in Ameralik. The recent SHRIMP and ID-TIMS U-Pb zircon ages of IGC granites (for example, Nutman and others, 1993, 1996, 2000; Crowley and others, 2002) confirms Baadsgaard and others (1986a) observations that they all have ages of $\leq 3660 \mathrm{Ma}$ and are related to high temperatures in an orogeny that reworked the older juvenile crust dominated by tonalites.

Finally, the dating program has largely confirmed the extent of the IGC, as originally defined using its lithological characteristics by McGregor (1973); that these rocks are cut by deformed, amphibolitized mafic dikes. A few exceptions to this have been found (Kinny, ms, 1987; Schiøtte and others, 1989b) where in the 1970s some rocks designated in the field as Eoarchean were discovered from U-Pb zircon dating to be Neoarchean in age. The relevant localities are marked in figure 1 by red circles. Overall, these have reduced the extent of the IGC by $<5$ percent.

In order to put all this information in an accessible format it is presented in five histograms backed by relative frequency distribution curves (fig. 8$)^{2}$. Figure 8 A shows the juvenile tonalite components from those parts of the IGC with the least migmatization during the 3660 to $3600 \mathrm{Ma}$ Isukasian orogeny. Note the clear distinction of oscillatory-zoned zircon giving tonalite ages at $\geq 3850 \mathrm{Ma}$ (subordinate), $3800 \mathrm{Ma}$ and $3700 \mathrm{Ma}$. The smear of ages down to $\sim 3600 \mathrm{Ma}$ is minimal, and this agrees with field observations that these rocks generally show only minor migmatization. Figure 8B shows strongly migmatized juvenile tonalitic components throughout the remaining parts of the IGC. Note here that although the same age peaks are apparent, plus a minor one at $\sim 3760 \mathrm{Ma}$, they are much less well defined, with a larger proportion of ages falling between 3660 to $3600 \mathrm{Ma}$. This is accounted for by recrystallization and partial ancient loss of radiogenic $\mathrm{Pb}$ from the protolith zircons. Thus recrystallized/ disturbed $\sim 3850$ Ma protolith zircons present a smear of apparent ages from 3850 to $3600 \mathrm{Ma}$; likewise similarly-affected $\sim 3700 \mathrm{Ma}$ protolith zircons also present a smear of

\footnotetext{
${ }^{2}$ Data have been subjected to filters of $\mathrm{f}_{206}<2 \%$ (where $\mathrm{f}_{206}$ is the proportion of ${ }^{206} \mathrm{~Pb}$ not of in situ uranogenic origin, based on measured ${ }^{204} \mathrm{~Pb}$ and Cumming and Richards (1975) model common $\mathrm{Pb}$ compositions) and differences in the ${ }^{207} \mathrm{~Pb} /{ }^{206} \mathrm{~Pb}$ and ${ }^{206} \mathrm{~Pb} /{ }^{238} \mathrm{U}$ ages of $<10 \%$, that is, $<10 \%$ discordant.
} 


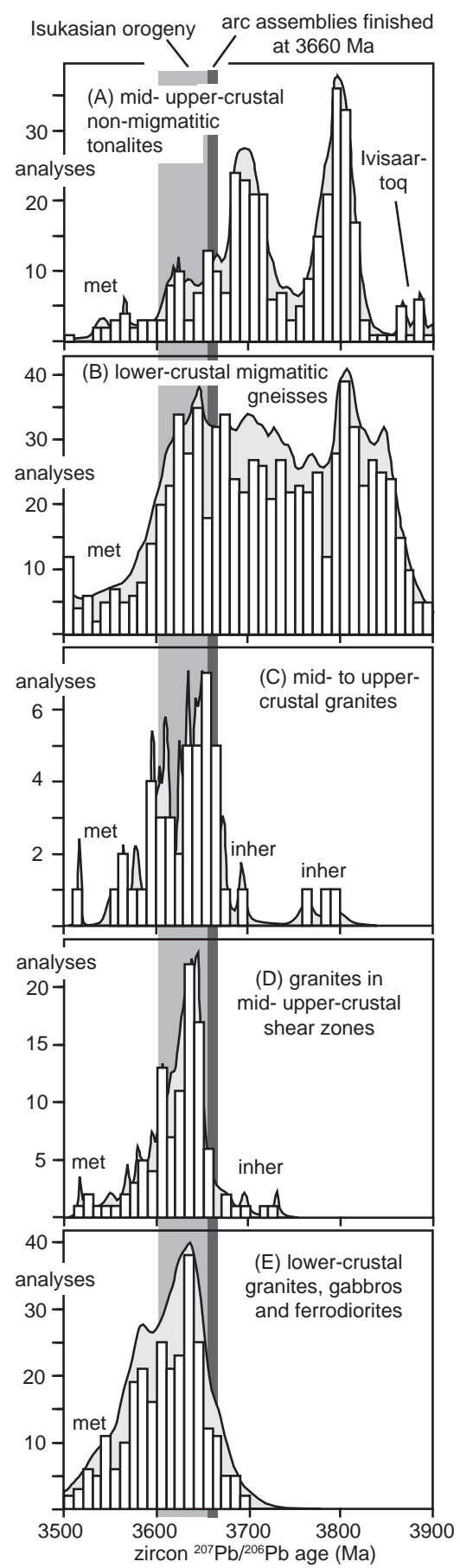

Fig. 8. Summary of SHRIMP U-Pb zircon ages from the Itsaq gneiss complex. The data are presented as follows: (A) tonalitic rocks and acid-intermediate volcanic rocks from areas with minimal superimposed migmatization, mostly upper- middle-crustal levels in the northern part of the complex; (B) tonalitic rocks throughout the rest of the complex where there is evidence of pervasive high temperature migmatization; $(\mathrm{C})$ granite intrusions in least migmatized upper- middle-crustal levels; (D) synkinematic granite intrusions along shear zones in upper- middle-crustal levels (E) granite and coeval gabbro intrusions in strongly migmatized lower-crustal levels. Inher $=$ inherited (pre-magmatic) zircon cores. Met $=<3600$ Ma metamorphic zircon. 
apparent ages from 3700 to $3600 \mathrm{Ma}$. This is in accord with the complex nature of these migmatites, and structurally complex zircons within them that display much regrowth and recrystallization (for example, Nutman and others, 2000; Horie and others, 2010). Figures 8C and 8D show the ages of zircons from granites exterior to and within shear zones, respectively, in the least-migmatized parts of the IGC. Note all granites formed post-3660 Ma, and that they carry only rare inherited zircon. Figure 8E shows ages of zircons from granites and coeval gabbros in formerly deep, migmatitic, parts of the IGC. Note that more than one age of intrusion is apparent, but there is a close match in ages with granites dated from non-migmatized parts of the IGC.

\section{Juvenile Crust Formation-Eoarchean Island Arcs?}

Information from the different-aged juvenile assemblages in the IGC, particularly the $\sim 3700 \mathrm{Ma}$ portion of the Isua supracrustal belt, chart out a history of crustal development with similarities to Phanerozoic crustal processes. Thus juvenile 3720 to $3710 \mathrm{Ma}$ crust development at Isua was initially by boninite, tholeiite and picrite eruption, with mafic tonalite and quartz-diorite intrusion (Polat and Hofmann, 2003; Nutman and others, 2007a; Friend and Nutman, 2010), but between 3710 to $3700 \mathrm{Ma}$ had evolved to maturity with formation of andesites, dacites, related sediments, and finally at 3700 to $3690 \mathrm{Ma}$, emplacement of tonalites and granodiorites (Nutman and others, 1996, 1997a, 2000, 2002b, 2007a, 2009; Crowley and others, 2002; Bohlar and others, 2005). The geochemical signatures of this assemblage of igneous rocks indicate magma generation for the mafic-intermediate suites by hydrous fluxing of the upper mantle and melting of eclogitized mafic crust for the quartzo-feldspathic suites (for example, Nutman and others, 1999; Polat and Hofmann, 2003; Dilek and Polat, 2009; Jenner and others, 2009; Nagel and others, 2012). This, combined with the age progression of different lithologies, the tectonic insertion of mantle dunite slivers by $3710 \mathrm{Ma}$ (Friend and Nutman, 2011) and the juvenile isotopic signatures (for example, Moorbath and others, 1972; Bennett and others, 1993; Hiess and others, 2009) all point to a strong resemblance with the sequence of rocks observed during development of intra-oceanic arc complexes (alternatively known as supra-subduction zone ophiolites; Shervais, 2001). Therefore we conclude that this is their most likely environment of formation. However, despite its lithological association, the 3720 to $3690 \mathrm{Ma}$ assemblage is not an intact section through a supra-subduction ophiolite, because, for example, convincing "sheeted dike" complexes have not been found (Friend and Nutman, 2010) and this assemblage was repeatedly partitioned by Eoarchean shear zones (Nutman and Friend, 2009).

The 3720 to 3690 Ma juvenile assemblage was juxtaposed to the south with a 3800 Ma complex, and hence it resembles Sierran-style ophiolites that are ensimatic island arc terranes accreted against older crust (Shervais, 2001 and references therein). This supports continuity of crust-formation processes at convergent plate boundaries for almost 4 billion years. The pattern of ages and lithological types in the rest of the IGC provide further evidence that this interpretation of crust formation was appropriate for all juvenile components from at least 3890 to $3660 \mathrm{Ma}$, although superimposed 3660 to $3600 \mathrm{Ma}$ and Neoarchean orogenies have destroyed most the field evidence that would support (or refute!) this contention.

\section{Contrasting Crustal Levels at 3660 to $3600 \mathrm{Ma}$}

The migmatites that dominate most of the IGC hold a record of sustained high temperatures at moderate pressures throughout the 3660 to 3600 Ma Isukasian orogeny (Friend and Nutman, 2005a). The $\sim 3700$ Ma tonalite terrane north of the Isua supracrustal belt shows evidence of hot (and deep) crustal conditions and ductile deformation at the start of the 3660 to 3600 Ma period, with a transition to cooler (and shallower?) conditions, with brittle failure at the end of the period. The $\sim 3800$ tonalite 
terrane south of the Isua supracrustal belt appears to show only cooler (shallow?) crustal conditions throughout this period.

In the Isua area, shear zones partition the products of juvenile crust production. Movements on these shear zones have been constrained to between 3645 to $3607 \mathrm{Ma}$, by the ages of pre- syn- and post-kinematic granite and pegmatite sheets involved with them (Crowley and others, 2002; Friend and others, 2002; Nutman and others, 2002b; data in this paper). These shear zones, combined with increasing evidence for extensional deformation, might be responsible for telescoping portions of the crust that resided in the deep, hot, ductile regime against those from a shallower, cooler, brittle regime (fig. 3B). New evidence for this comes from the $\sim 3700$ Ma tonalite complex north of the Isua supracrustal belt, which at $\sim 3650$ Ma was in a hot ductile regime with incipient migmatization (fig. 4C) but by 3600 Ma had been transferred to a cooler regime with deformation by cataclasis (fig. 4F). Titanite U-Pb dates of $3606 \pm$ $3 \mathrm{Ma}$ (from a $3659 \mathrm{Ma}$ Inaluk dyke), $3606 \pm 3 \mathrm{Ma}$ (from a $3698 \pm 2 \mathrm{Ma}$ tonalite) and $3603 \pm 3 \mathrm{Ma}$ (from a $\sim 3645 \mathrm{Ma}$ granite; Crowley and others, 2002) are in accord with this interpretation.

\section{The Nature of the 3660 to 3600 Ma Isukasian Orogeny}

The whole of the IGC was affected by the Isukasian orogeny. Thus the Isukasian orogen covered a larger expanse of Eoarchean "continental" crust than just the IGC, with this larger crustal mass being fragmented and dispersed starting from $\sim 3500 \mathrm{Ma}$, as marked by intrusion of the Ameralik dykes. This is analogous to the way that on either side of the South Atlantic there is Precambrian crust affected by the Neoproterozoic Brasiliano orogen in South America and the Pan African orogen in Africa-these being dispersed fragments of continental crust affected within a larger orogenic system.

Understanding the geodynamic framework of the Isukasian orogen is impeded not only by fragmentation, but also because its surviving pieces have only small areas that were not reworked in superimposed post-3500 Ma orogenic events (Nutman and others, 1996). Furthermore, thermo-mechanical modelling (for example, Duclaux and others, 2007; Rey and Coltice, 2008) shows the much greater heat production from radionuclides in the Archean than today means that, compared with modern collisional orogens, tectonically thickened crust in the Eoarchean had greater propensity to undergo deep crustal anatexis and collapse. The greater degree of partial melting made the Eoarchean deep crust very mobile and thereby destroyed much of the evidence on the mechanism of previous crustal thickening (figs. 3C and 4A). This is a significant handicap, because most of the surviving IGC was in the deep crust during the Isukasian orogeny. Notwithstanding, models to explain the Isukasian orogeny must account for the following:

(1) It was a sustained event lasting for $\sim 50$ million years, as shown by 3660 to 3610 Ma zircon ages of migmatization and granite bodies (figs. $8 \mathrm{C}-8 \mathrm{E}$ ), followed by U-Pb closure of the titanite at $\sim 3605 \mathrm{Ma}^{3}$ (for example, Nutman and others, 2000; Crowley and others, 2002; Friend and others, 2002; Friend and Nutman, 2005a).

(2) There is mounting evidence suggesting extensional deformation was important during the orogeny; (i) at middle-upper crustal levels granite sheets were emplaced into extensional fractures; (ii) a major Eoarchean shear zone in the eastern end of the Isua supracrustal belt has kyanite-bearing upper amphibolite facies rocks in the footwall and greenschist to epidote-amphibolite rocks in the hangingwall (fig. 3B)

\footnotetext{
${ }^{3}$ This key piece of information has been obliterated from most of the Itsaq Gneiss Complex by superimposed tectonothermal events, but survives in the plutonic complex of $c a .3700$ Ma tonalites and granite sheets north of the Isua supracrustal belt.
} 
and (iii) in the melt-lubricated deep crustal migmatites, 3640 Ma composite granitegabbro intrusions show syn-magmatic extensional features (fig. $4 \mathrm{H}$ ).

(3) The event followed on from $\geq 3900$ to 3660 Ma juvenile crustal growth without high temperature metamorphism (Nutman and others, 1993; Bennett and others, 1993). This appears to have been terminated by the start of the orogeny, with transient high-pressure metamorphism (newly-discovered high pressure granulitesee above) and then a switchover to crustal recycling marked by an elevated geothermal gradient and deep crustal melting at moderate pressures (Friend and Nutman, 2005a).

Thus modern analogs must involve crustal reworking following assembly of unrelated terranes, with protracted high heat flow taking place in an overall extensional regime. A possible analog is continental northeast Asia, which following final early Mesozoic assembly of arc terranes and older continental blocks, has suffered quasi-continuous extension up to the present time. This has caused extensive crustal thinning, with the widespread development of core complexes, particularly in the Cretaceous (for example, Ren and others, 2002; Yang and others, 2007). Extension has been to the extent that the underlying lithospheric mantle has been largely removed (for example, Fan and others, 2000). There is still debate concerning the cause of this high heat flow extensional regime. However, one potential control is the continual eastward roll-back of subduction systems into the northern Pacific, promoting behind it continued extension of continental northeastern Asia (for example, Wei and others, 2012 and references therein).

In reality, establishing the geodynamic setting of the Isukasian orogeny is hampered by the small size of the IGC-in the modern context it would be hard to establish the geodynamic setting of the entire Himalayan-European Alps system based on only $3000 \mathrm{~km}^{2}$ of amphibolite facies tectonites!

\section{CONCLUSIONS}

(1) Four decades of research with increasingly sophisticated isotopic analytical techniques all indicate that Eoarchean crust embodied by the Itsaq Gneiss Complex was extracted from a depleted upper mantle reservoir in the Eoarchean; that is it was juvenile at that time and not formed from recycled Hadean material.

(2) The accrued zircon U-Pb geochronology shows that juvenile crustal components are not a single generation, but formed in several episodes from $\sim 3900$ to $\sim 3660$ Ma.

(3) Juvenile crust domains of different age are mutually exclusive, and evidence from around the Isua supracrustal belt shows that they were tectonically assembled by $3660 \mathrm{Ma}$. This indicates that the crust grew by lateral accretion.

(4) The geochemistry of the juvenile Eoarchean igneous rocks points to derivation by partial melting of eclogitized (and maybe also high-pressure granulite) mafic rocks and fluid-fluxing of upper mantle peridotite. This suggests these rocks formed at convergent plate boundaries in environments akin to modern supra-subduction zone settings. The detailed chronology obtained from the $\sim 3700$ Ma portion of the Isua supracrustal belt shows a mafic to felsic progression from 3720 to 3710 Ma basalts/ gabbros, 3710 to $3700 \mathrm{Ma}$ andesites/diorites to $\sim 3690 \mathrm{Ma}$ tonalites, and suggests these rocks are samples of arcs evolving over a time span of 10 to 25 million years.

(5) Within the extent of the present Itsaq Gneiss Complex, juvenile crust production ceased at $\sim 3660 \mathrm{Ma}$, and was followed by the Isukasian orogeny which lasted to $3600 \mathrm{Ma}$. The isotopic signatures of 3650 to 3600 Ma granites formed during the Isukasian orogeny demonstrate that they were at least partially derived from slightly older, isotopically evolved, crustal components. The hallmark of this orogeny was elevated heat flow with migmatization of much of the lower crust, and granite 
emplacement at higher levels. There is increasing structural evidence for extensional deformation being prevalent after inception of the orogen.

(6) Given (i) the overall small size of the Itsaq Gneiss Complex, (ii) the even smaller area in it where structures relating to the 3660 to $3600 \mathrm{Ma}$ orogen are preserved, and (iii) that it represents just a fragment of the larger Isukasian orogen, it is not yet possible to identify with certainty the broader geodynamic setting of the orogen. A possible scenario for further exploration is extension following northeastern Asian-style early Mesozoic terrane assembly and subsequent Pacific-ward eastward migration of subduction systems.

(7) The accrued body of knowledge from the Itsaq Gneiss Complex shows that Eoarchean crust-forming events and orogeny had strong similarities with processes operating in the Phanerozoic, and indicate that some form of plate tectonics operated almost 4 billion years ago.

\section{ACKNOWLEDGEMENTS}

We thank J. E. Hoffman, P. Cawood and Guest Editor S. Wilde for their constructive and thoughtful reviews. Research on the Itsaq Gneiss Complex was supported by NERC grant NER/A/S/1999/00024, ARC grants DP0342798, DP110104981, the Korean Basic Science Institute, the University of Wollongong GeoQuEST Research Centre and Hiroshima University. 
ApPendix 1

TABLE Al

Summary of SHRIMP U-Pb zircon data for high-pressure granulite segregation G11/24

\begin{tabular}{|c|c|c|c|c|c|c|c|c|c|c|c|c|}
\hline Spot & site & $\begin{array}{c}\mathrm{U} \\
\mathrm{ppm}\end{array}$ & $\begin{array}{c}\text { Th } \\
\text { ppm }\end{array}$ & $\frac{T h}{U}$ & $\begin{array}{c}\% \\
{ }^{206} \mathrm{~Pb}_{\mathrm{c}}\end{array}$ & $\frac{{ }^{238} \mathrm{U}}{{ }^{206} \mathrm{~Pb}^{*}}$ & $\pm \%$ & $\frac{{ }^{207} \mathrm{~Pb}^{*}}{{ }^{206} \mathrm{~Pb}^{*}}$ & $\pm \%$ & $\frac{{ }^{207} \mathrm{P}}{{ }^{206} \mathrm{P}}$ & & $\begin{array}{c}\% \\
\text { Disc. }\end{array}$ \\
\hline $24 \mathrm{~A}-1.1$ & e,osc,eq & 56 & 0.50 & 0.009 & 0.19 & 1.268 & 1.3 & 0.3372 & 0.49 & 3650 & \pm 7 & -4 \\
\hline $24 \mathrm{~A}-2.1$ & e,osc,eq & 116 & 0.65 & 0.006 & 0.10 & 1.327 & 1.0 & 0.3390 & 0.33 & 3658 & \pm 5 & +1 \\
\hline $24 A-3.1$ & $e, o s c+r e x, e q$ & 84 & 1.26 & 0.015 & 0.10 & 1.286 & 1.1 & 0.3374 & 0.39 & 3651 & \pm 6 & -2 \\
\hline $24 \mathrm{~A}-4.1$ & e,h/rex,p & 152 & 1.95 & 0.013 & 0.08 & 1.308 & 0.9 & 0.3351 & 0.30 & 3641 & \pm 5 & -1 \\
\hline $24 A-4.2$ & $m, o s c+r e x, p$ & 61 & 1.83 & 0.030 & 0.13 & 1.341 & 1.3 & 0.3369 & 0.47 & 3649 & \pm 7 & +2 \\
\hline $24 \mathrm{~A}-5.1$ & e,osc,p & 64 & 1.19 & 0.019 & 0.12 & 1.319 & 1.3 & 0.3407 & 0.46 & 3666 & \pm 7 & +1 \\
\hline $24 \mathrm{~A}-5.2$ & $\mathrm{~m}, \mathrm{rex}, \mathrm{p}$ & 7 & 0.70 & 0.099 & 1.56 & 1.515 & 3.7 & 0.3310 & 1.83 & 3622 & \pm 28 & +12 \\
\hline $24 A-6.1$ & e,rex,eq & 35 & 1.23 & 0.035 & 0.34 & 1.317 & 1.8 & 0.3345 & 0.73 & 3638 & \pm 11 & -0 \\
\hline $24 \mathrm{~A}-7.1$ & e,osc,p & 17 & 0.30 & 0.018 & 1.38 & 1.332 & 2.5 & 0.3374 & 1.25 & 3651 & \pm 19 & +1 \\
\hline $24 A-8.1$ & $e, o s c+r e x, e q$ & 64 & 0.19 & 0.003 & 0.02 & 1.279 & 1.3 & 0.3372 & 0.46 & 3650 & \pm 7 & -3 \\
\hline $24 \mathrm{~A}-9.1$ & e,rex,p & 46 & 0.51 & 0.011 & 0.20 & 1.313 & 1.5 & 0.3332 & 1.00 & 3632 & \pm 15 & -1 \\
\hline $24 \mathrm{~A}-10.1$ & e,h/rex,p & 33 & 0.55 & 0.017 & 0.36 & 1.355 & 1.8 & 0.3307 & 0.73 & 3620 & \pm 11 & +2 \\
\hline $24 \mathrm{~A}-11.1$ & $\mathrm{e}, \mathrm{h} / \mathrm{rex}, \mathrm{p}$ & 36 & 0.15 & 0.004 & 0.15 & 1.283 & 1.6 & 0.3339 & 0.60 & 3635 & \pm 9 & -3 \\
\hline $24 \mathrm{~A}-11.2$ & $\mathrm{~m}, \mathrm{osc}, \mathrm{p}$ & 13 & 0.13 & 0.010 & 0.35 & 1.345 & 2.5 & 0.3409 & 1.00 & 3667 & \pm 15 & +3 \\
\hline $24 \mathrm{~A}-12.1$ & $\mathrm{e}, \mathrm{h} / \mathrm{rex}$ & 60 & 0.56 & 0.009 & 0.08 & 1.318 & 1.2 & 0.3317 & 0.45 & 625 & \pm 7 & -1 \\
\hline $24 \mathrm{~A}-12.2$ & $\mathrm{~m}, \mathrm{rex} / \mathrm{osc}, \mathrm{p}$ & 4 & 0.19 & 0.044 & 1.39 & 1.450 & 4.7 & 0.3413 & 2.27 & 3668 & \pm 35 & +10 \\
\hline $24 \mathrm{~A}-13.1$ & $\mathrm{~m}, \mathrm{osc}, \mathrm{p}$ & 129 & 0.51 & 0.004 & 0.02 & 1.345 & 0.9 & 0.3407 & 0.31 & 3666 & \pm 5 & +3 \\
\hline $24 \mathrm{~A}-14.1$ & $\mathrm{~m}, \mathrm{osc}, \mathrm{p}$ & 85 & 0.16 & 0.002 & 0.12 & 1.352 & 1.1 & 0.3410 & 0.40 & 3667 & \pm 6 & +3 \\
\hline $24 \mathrm{~A}-15.1$ & e,sz,p & 94 & 1.64 & 0.017 & 0.32 & 1.286 & 1.4 & 0.3245 & 0.54 & 3591 & \pm 8 & -4 \\
\hline $24 \mathrm{~A}-15.2$ & $\mathrm{e}, \mathrm{osc}, \mathrm{p}$ & 21 & 0.27 & 0.013 & 0.31 & 1.301 & 2.0 & 0.3412 & 0.84 & 3668 & \pm 13 & -0 \\
\hline $24 B-$ & $e, h+o s$ & 50 & 0.18 & 0.004 & 0.16 & 1.326 & 1.5 & 0.3338 & 0.55 & 3634 & \pm 8 & +0 \\
\hline $24 B-2.1$ & $\mathrm{e}, \mathrm{h}, \mathrm{p}$ & 269 & 5.18 & 0.019 & 0.09 & 1.384 & 0.8 & 0.3244 & 0.23 & 3591 & \pm 4 & +3 \\
\hline $24 B-2.2$ & $\mathrm{~m}, \mathrm{rex} / \mathrm{h}, \mathrm{p}$ & 10 & 0.23 & 0.022 & 1.37 & 1.731 & 3.4 & 0.3470 & 1.93 & 3694 & \pm 29 & +25 \\
\hline $24 \mathrm{~B}-3.1$ & e,osc,eq & 109 & 0.16 & 0.001 & 0.09 & 1.304 & 1.0 & 0.3377 & 0.36 & 3652 & \pm 5 & -1 \\
\hline $24 \mathrm{~B}-4.1$ & & 83 & 1.02 & 0.012 & 0.06 & 1.351 & 1.2 & 0.3303 & 0.43 & 3618 & \pm 7 & +2 \\
\hline 24B-5.1 & $\mathrm{e}, \mathrm{sz}$ & 76 & 0.60 & 0.008 & 0.02 & 1.329 & 1 & 0.3345 & 0.45 & 638 & \pm & +1 \\
\hline $24 B-5.2$ & e,osc,p & 153 & 0.21 & 0.019 & 0.03 & 1.314 & 0.9 & 0.3373 & 0.32 & 3651 & \pm 5 & +0 \\
\hline $24 B-6.1$ & e,sz,p & 95 & 1.80 & 0.019 & 0.06 & 1.288 & 1.1 & 0.3326 & 0.40 & 3629 & \pm 6 & -3 \\
\hline $24 B-7.1$ & e,sz/rex,p & 94 & 2.67 & 0.028 & 0.10 & 1.345 & 1.1 & 0.3328 & 0.39 & 3630 & \pm 6 & +2 \\
\hline $24 B-7.2$ & $\mathrm{~m}, \mathrm{osc}, \mathrm{p}$ & 109 & 0.67 & 0.006 & 0.04 & 1.293 & 1.0 & 0.3388 & 0.35 & 3657 & \pm 5 & -1 \\
\hline $24 \mathrm{~B}-8.1$ & $\mathrm{e}, \mathrm{sz}, \mathrm{p}$ & 281 & 1.42 & 0.005 & 0.05 & 1.442 & 1.0 & 0.2532 & 0.22 & 3205 & \pm 4 & -8 \\
\hline $24 \mathrm{~B}-$ & & 78 & 1.01 & 0.013 & 0.72 & 1.269 & 1 & 0.3381 & 0.50 & 554 & \pm 8 & -3 \\
\hline $24 \mathrm{~B}-10.1$ & e,osc,eq,fr & 67 & 1.30 & 0.019 & 0.13 & 1.287 & 1.2 & 0.3381 & 0.45 & 3654 & \pm 7 & -2 \\
\hline $24 \mathrm{~B}-11.1$ & $\mathrm{e}, \mathrm{sz}, \mathrm{p}$ & 71 & 0.29 & 0.004 & 0.05 & 1.359 & 1.2 & 0.3225 & 0.43 & 3582 & \pm 7 & +1 \\
\hline 24B-11.2 & $\mathrm{m}, \mathrm{osc}, \mathrm{p}$ & 17 & 0.73 & 0.042 & 0.18 & 1.300 & 2.3 & 0.3455 & 0.86 & 3687 & \pm 13 & +0 \\
\hline $24 B-12.1$ & $e, r e x+o s c, p$ & 66 & 0.48 & 0.007 & 0.15 & 1.332 & 1.2 & 0.3366 & 0.45 & 3648 & \pm 7 & +1 \\
\hline $24 B-12.2$ & $\mathrm{~m}, \mathrm{osc}, \mathrm{p}$ & 197 & 0.30 & 0.002 & 0.05 & 1.348 & 0.8 & 0.3381 & 0.25 & 3654 & \pm 4 & +3 \\
\hline $24 \mathrm{~B}-$ & & 110 & 0.56 & & 0.15 & 1.246 & 1 & & 0.37 & & \pm 6 & -6 \\
\hline 24B- & $\mathrm{m}, \mathrm{h}$,eq,fr & 9 & 0.26 & 0.029 & 1.47 & 1.357 & 2.9 & 0.3246 & 1.39 & 3592 & \pm 21 & +1 \\
\hline 24B-13.2 & e,h,eq,fr & 82 & 1.92 & 0.023 & 0.07 & 1.287 & 1.1 & 0.3336 & 0.40 & 3634 & \pm 6 & -3 \\
\hline $24 \mathrm{~B}-14.1$ & $\mathrm{e}, \mathrm{h} / \mathrm{rex}, \mathrm{p}$ & 62 & 2.17 & 0.035 & 0.19 & 1.271 & 1.3 & 0.3321 & 0.49 & 3627 & \pm 7 & -4 \\
\hline 24B-14.2 & $\mathrm{m}, \mathrm{osc}, \mathrm{p}$ & 88 & 1.00 & 0.011 & 0.05 & 1.334 & 1.1 & 0.3384 & 0.38 & 3656 & \pm 6 & +2 \\
\hline $24 B-15.1$ & $e, h /$ rex $^{2}$ & 216 & 2.51 & 0.012 & 0.08 & 1.452 & 0.8 & 0.3326 & 0.43 & 3629 & \pm 7 & +9 \\
\hline $24 \mathrm{~B}-15.2$ & m,osc,e & 50 & 1.26 & 0.026 & 0.13 & 1.284 & 1.5 & 0.3392 & 0.59 & 3659 & \pm 9 & -2 \\
\hline 24B-9.1 & m,osc,eq & 85 & 0.33 & 0.004 & 0.08 & 1.300 & 1.1 & 0.3377 & 0.38 & 3652 & \pm 6 & -1 \\
\hline $24 \mathrm{C}-1.1$ & e,sz,p,fr & 76 & 0.82 & 0.011 & 0.25 & 1.345 & 1.2 & 0.3260 & 0.47 & 3598 & \pm 7 & +1 \\
\hline $24 \mathrm{C}-1.2$ & $\mathrm{~m}, \mathrm{osc}, \mathrm{p}, \mathrm{fr}$ & 105 & 0.23 & 0.002 & 0.08 & 1.286 & 1.0 & 0.3362 & 0.35 & 3646 & \pm 5 & -2 \\
\hline $24 C-2.1$ & e,sz,p,fr & 558 & 6.06 & 0.011 & 0.22 & 3.329 & 0.7 & 0.2947 & 0.29 & 3442 & \pm 4 & +57 \\
\hline $24 C-2.2$ & e,sz,p,fr & 166 & 0.56 & 0.003 & 0.05 & 1.483 & 0.9 & 0.3353 & 0.31 & 3642 & \pm 5 & +11 \\
\hline $24 C-2.3$ & $\mathrm{~m}, \mathrm{osc}, \mathrm{p}, \mathrm{fr}$ & 84 & 0.46 & 0.005 & 0.07 & 1.324 & 1.1 & & 0.41 & 3652 & \pm 6 & +1 \\
\hline $24 C-3.1$ & e,h/rex,p & 250 & 0.81 & 0.003 & 0.03 & 1.328 & 0.8 & 0.3340 & 0.41 & 3636 & \pm 6 & +1 \\
\hline $24 C-3.2$ & $\mathrm{~m}, \mathrm{osc}, \mathrm{p}$ & 73 & 0.86 & 0.012 & 0.09 & 1.377 & 1.2 & 0.3389 & 0.43 & 3658 & \pm 7 & +5 \\
\hline $24 C-3.3$ & $\mathrm{e}, \mathrm{h} / \mathrm{rex}, \mathrm{p}$ & 213 & 1.64 & 0.008 & 0.11 & 1.315 & 0.8 & 0.3352 & 0.25 & 3641 & \pm 4 & -0 \\
\hline $24 \mathrm{C}-4.1$ & e,h/rex,p & 227 & 2.96 & 0.013 & 0.09 & 1.538 & 0.8 & 0.3275 & 0.26 & 3606 & \pm 4 & +13 \\
\hline
\end{tabular}


Ma juvenile crust formation and recycling in the 3660 to 3600 Ma Isukasian orogeny 905

TABLE A1

(continued)

\begin{tabular}{|c|c|c|c|c|c|c|c|c|c|c|c|c|}
\hline Spot & site & $\begin{array}{c}\mathrm{U} \\
\mathrm{ppm}\end{array}$ & $\begin{array}{c}\text { Th } \\
\mathrm{ppm}\end{array}$ & $\frac{\mathrm{Th}}{\mathrm{U}}$ & $\begin{array}{c}\% \\
{ }^{206} \mathrm{~Pb}_{\mathrm{c}}\end{array}$ & $\frac{{ }^{238} \mathrm{U}}{{ }^{206} \mathrm{~Pb}^{*}}$ & $\pm \%$ & $\frac{{ }^{207} \mathrm{~Pb}^{*}}{{ }^{206} \mathrm{~Pb}^{*}}$ & $\pm \%$ & \multicolumn{2}{|c|}{$\frac{{ }^{207} \mathrm{~Pb}}{{ }^{206} \mathrm{~Pb}}$ age } & $\begin{array}{c}\% \\
\text { Disc. }\end{array}$ \\
\hline $24 C-4.2$ & $\mathrm{~m}, \mathrm{~h} / \mathrm{rex}, \mathrm{p}$ & 1126 & 14.30 & 0.013 & 0.02 & 1.378 & 0.6 & 0.3303 & 0.11 & 3618 & \pm 2 & +4 \\
\hline $24 C-5.1$ & e,osc,p,fr & 98 & 0.31 & 0.003 & 0.11 & 1.310 & 1.0 & 0.3372 & 0.36 & 3650 & \pm 5 & -0 \\
\hline $24 C-5.2$ & $\mathrm{~m}, \mathrm{osc}, \mathrm{p}, \mathrm{fr}$ & 131 & 3.57 & 0.027 & 0.04 & 1.296 & 0.9 & 0.3406 & 0.30 & 3666 & \pm 5 & -1 \\
\hline $24 C-6.1$ & $m, o s c+r e x, e q$ & 90 & 0.54 & 0.006 & 0.08 & 1.333 & 1.0 & 0.3366 & 0.37 & 3648 & \pm 6 & +1 \\
\hline $24 \mathrm{C}-7.1$ & $\mathrm{e}, \mathrm{h} / \mathrm{rex}, \mathrm{p}$ & 202 & 1.78 & 0.009 & 0.02 & 1.304 & 0.8 & 0.3337 & 0.24 & 3634 & \pm 4 & -1 \\
\hline $24 C-7.2$ & $\mathrm{~m}, \mathrm{osc}, \mathrm{p}$ & 50 & 0.28 & 0.006 & 0.07 & 1.292 & 1.4 & 0.3396 & 0.50 & 3661 & \pm 8 & -1 \\
\hline $24 C-8.1$ & $\mathrm{~m}, \mathrm{osc}, \mathrm{p}$ & 27 & 0.74 & 0.027 & 0.30 & 1.295 & 1.7 & 0.3378 & 0.69 & 3653 & \pm 11 & -1 \\
\hline $24 C-8.2$ & e,h/rex,p & 88 & 2.01 & 0.023 & 0.06 & 1.272 & 1.1 & 0.3326 & 0.39 & 3629 & \pm 6 & -4 \\
\hline $24 C-9.1$ & e,rex,p & 224 & 0.25 & 0.001 & 0.04 & 1.304 & 0.8 & 0.3363 & 0.23 & 3646 & \pm 4 & -1 \\
\hline $24 C-9.2$ & $\mathrm{~m}, \mathrm{osc}, \mathrm{p}$ & 54 & 0.26 & 0.005 & 0.18 & 1.325 & 1.3 & 0.3462 & 0.48 & 3690 & \pm 7 & +2 \\
\hline $24 \mathrm{C}-10.1$ & $\mathrm{e}, \mathrm{h} / \mathrm{rex}, \mathrm{p}, \mathrm{fr}$ & 469 & 1.48 & 0.003 & 0.04 & 2.896 & 1.0 & 0.2830 & 0.61 & 3380 & \pm 9 & +50 \\
\hline $24 \mathrm{C}-10.2$ & $\mathrm{~m}, \mathrm{osc}, \mathrm{p}, \mathrm{fr}$ & 96 & 0.28 & 0.003 & 0.09 & 1.292 & 1.0 & 0.3383 & 0.36 & 3655 & \pm 5 & -1 \\
\hline $24 \mathrm{C}-10.3$ & $\mathrm{~m}, \mathrm{rex}, \mathrm{p}, \mathrm{fr}$ & 234 & 1.44 & 0.006 & 0.04 & 1.320 & 0.8 & 0.3331 & 0.23 & 3631 & \pm 4 & -0 \\
\hline $24 \mathrm{C}-10.4$ & $\mathrm{~m}, \mathrm{rex}, \mathrm{p}, \mathrm{fr}$ & 5 & 0.07 & 0.014 & 0.68 & 1.400 & 3.8 & 0.3314 & 2.45 & 3624 & \pm 38 & +5 \\
\hline $24 \mathrm{C}-11.1$ & $\mathrm{e}, \mathrm{h} / \mathrm{rex}, \mathrm{p}$ & 174 & 1.25 & 0.007 & 0.09 & 1.342 & 0.8 & 0.3356 & 0.27 & 3643 & \pm 4 & +2 \\
\hline $24 \mathrm{C}-11.2$ & e,h/rex,p & 720 & 2.00 & 0.003 & 0.03 & 1.376 & 0.6 & 0.3310 & 0.13 & 3622 & \pm 2 & +4 \\
\hline $24 \mathrm{C}-11.3$ & $\mathrm{~m}, \mathrm{~h} / \mathrm{rex}, \mathrm{p}$ & 4008 & 1.39 & 0.000 & 0.60 & 9.173 & 0.8 & 0.1421 & 2.13 & 2253 & \pm 37 & +74 \\
\hline $24 \mathrm{D}-2.2$ & $\mathrm{e}, \mathrm{h} / \mathrm{rex}, \mathrm{eq}$ & 122 & 0.42 & 0.003 & 0.17 & 1.574 & 1.0 & 0.3276 & 0.36 & 3606 & \pm 6 & +15 \\
\hline 24D-1.1 & $\mathrm{m} / \mathrm{c}, \mathrm{osc}, \mathrm{p}$ & 20 & 0.08 & 0.004 & 0.66 & 1.317 & 2.2 & 0.3453 & 0.89 & 3686 & \pm 14 & +2 \\
\hline $24 \mathrm{D}-1.2$ & $\mathrm{e}, \mathrm{h} / \mathrm{rex}, \mathrm{p}$ & 48 & 0.96 & 0.020 & 0.26 & 1.344 & 1.4 & 0.3258 & 0.57 & 3597 & \pm 9 & +0 \\
\hline $24 \mathrm{D}-2.1$ & $\mathrm{e}, \mathrm{h} / \mathrm{rex}, \mathrm{eq}$ & 1 & 0.02 & 0.044 & 9.23 & 1.557 & 17.6 & 0.4490 & 8.40 & 4082 & \pm 125 & +27 \\
\hline 24D-3.1 & $\mathrm{m}, \mathrm{h} / \mathrm{rex}, \mathrm{p}$ & 2 & 0.04 & 0.018 & 3.67 & 1.367 & 6.3 & 0.3031 & 5.36 & 3486 & \pm 83 & -2 \\
\hline 24D-4.1 & $\mathrm{m}, \mathrm{osc}, \mathrm{p}$ & 35 & 0.19 & 0.006 & 0.16 & 1.314 & 1.6 & 0.3374 & 0.62 & 3651 & \pm 9 & +0 \\
\hline $24 D-4.2$ & $e, o s c+r e x, p$ & 1515 & 1.42 & 0.001 & 0.14 & 1.963 & 1.3 & 0.2038 & 0.45 & 2857 & \pm 7 & +9 \\
\hline 24D-5.1 & $\mathrm{e}, \mathrm{osc}, \mathrm{p}$ & 87 & 0.49 & 0.006 & 0.14 & 1.312 & 1.2 & 0.3262 & 0.43 & 3599 & \pm 7 & -2 \\
\hline $24 D-5.2$ & $\mathrm{~m}, \mathrm{rex} / \mathrm{h}, \mathrm{p}$ & 9 & 0.22 & 0.024 & 0.45 & 1.297 & 3.0 & 0.3345 & 1.22 & 3638 & \pm 19 & -2 \\
\hline $24 \mathrm{D}-6.1$ & $\mathrm{~m}, \mathrm{osc}, \mathrm{p}$ & 13 & 0.32 & 0.025 & 0.42 & 1.308 & 2.5 & 0.3382 & 1.00 & 3655 & \pm 15 & -0 \\
\hline 24D-6.2 & e,h/rex,p & 77 & 0.38 & 0.005 & 0.05 & 1.303 & 1.1 & 0.3331 & 0.41 & 3631 & \pm 6 & -1 \\
\hline 24D-7.1 & m,rex,eq & 6 & 0.05 & 0.009 & 2.70 & 1.380 & 4.0 & 0.3187 & 2.31 & 3564 & \pm 36 & +2 \\
\hline $24 \mathrm{D}-7.2$ & e,rex,eq & 128 & 0.92 & 0.007 & 0.12 & 1.271 & 0.9 & 0.3332 & 0.32 & 3632 & \pm 5 & -4 \\
\hline 24D-8.1 & $\mathrm{m}, \mathrm{osc}, \mathrm{eq}$ & 8 & 0.08 & 0.010 & 1.15 & 1.401 & 3.2 & 0.3407 & 2.51 & 3666 & \pm 38 & +7 \\
\hline 24D-8.2 & e,rex,eq & 293 & 0.68 & 0.002 & 0.22 & 1.548 & 0.7 & 0.2908 & 0.26 & 3422 & \pm 4 & +8 \\
\hline 24D-9.1 & $\mathrm{m}, \mathrm{rex}+\mathrm{osc}, \mathrm{p}$ & 8 & 0.03 & 0.003 & 2.07 & 1.353 & 3.3 & 0.3496 & 1.62 & 3705 & \pm 25 & +5 \\
\hline 24D-9.2 & e,h/rex,p & 64 & 1.35 & 0.021 & 0.18 & 1.281 & 1.2 & 0.3321 & 0.47 & 3627 & \pm 7 & -3 \\
\hline 24D-10.1 & $\mathrm{m}, \mathrm{rex}, \mathrm{p}$ & 3 & 0.09 & 0.036 & 3.56 & 1.366 & 6.0 & 0.3720 & 3.33 & 3800 & \pm 50 & +9 \\
\hline $24 D-10.2$ & ( & 82 & 0.18 & 0.002 & 0.19 & 1.301 & 1.2 & 0.3268 & 0.48 & 3602 & \pm 7 & -3 \\
\hline 24D-11.1 & $\mathrm{m}, \mathrm{osc}, \mathrm{eq}$ & 19 & 0.03 & 0.001 & 0.37 & 1.413 & 2.3 & 0.3381 & 0.98 & 3654 & \pm 15 & +7 \\
\hline $24 D-11.2$ & $e, o s c+r e x, e q$ & 89 & 0.59 & 0.007 & 0.03 & 1.301 & 1.1 & 0.3376 & 0.38 & 3652 & \pm 6 & -1 \\
\hline $24 D-12.1$ & $m, o s c+r e x, p$ & 2 & 0.08 & 0.038 & 1.08 & 1.287 & 6.1 & 0.3463 & 2.59 & 3691 & \pm 39 & -1 \\
\hline 24D-12.2 & e,h/rex,p & 98 & 1.04 & 0.011 & 0.02 & 1.285 & 1.0 & 0.3372 & 0.36 & 3650 & \pm 6 & -2 \\
\hline 24D-13.1 & $\mathrm{m}, \mathrm{osc}, \mathrm{p}$ & 35 & 0.19 & 0.005 & 0.20 & 1.281 & 1.6 & 0.3386 & 0.62 & 3657 & \pm 9 & -2 \\
\hline 24D-13.2 & e,rex/h,p & 85 & 1.91 & 0.023 & 0.08 & 1.400 & 1.1 & 0.3141 & 0.41 & 3541 & \pm 6 & +2 \\
\hline 24D-14.1 & e.rex,p,fr & 68 & 0.36 & 0.005 & 0.30 & 1.328 & 1.3 & 0.3314 & 0.84 & 3624 & \pm 13 & +0 \\
\hline 24D-15.1 & m,rex,p & 6 & 0.02 & 0.004 & 0.49 & 1.289 & 3.7 & 0.3643 & 1.44 & 3768 & \pm 22 & +2 \\
\hline 24D-15.2 & e,h/rex,p & 76 & 0.94 & 0.012 & 0.07 & 1.273 & 1.2 & 0.3341 & 0.41 & 3636 & \pm 6 & -4 \\
\hline 24D-16.1 & $\mathrm{m}, \mathrm{rex} / \mathrm{h}, \mathrm{p}$ & 3 & 0.02 & 0.007 & 1.54 & 1.530 & 5.0 & 0.3553 & 4.66 & 3730 & \pm 71 & +17 \\
\hline $24 D-16.2$ & $e, r e x+o s c, p$ & 65 & 0.34 & 0.005 & 0.06 & 1.322 & 1.2 & 0.3373 & 0.43 & 3651 & \pm 7 & +1 \\
\hline $24 D-17.1$ & $e, r e x+o s c, p$ & 39 & 0.97 & 0.025 & 0.39 & 1.315 & 1.5 & 0.3376 & 0.95 & 3652 & \pm 15 & +0 \\
\hline $24 \mathrm{D}-18.1$ & $\mathrm{~m}, \mathrm{osc}, \mathrm{p}$ & 97 & 1.37 & 0.014 & 0.04 & 1.296 & 1.0 & 0.3376 & 0.34 & 3652 & \pm 5 & -1 \\
\hline 24D-18.2 & e,rex/h,p & 73 & 0.51 & 0.007 & 0.07 & 1.265 & 1.2 & 0.3335 & 0.43 & 3633 & \pm 7 & -4 \\
\hline $24 D-19.2$ & $e, r e x+o s c, p$ & 43 & 0.71 & 0.016 & 0.09 & 1.294 & 1.4 & 0.3364 & 0.52 & 3646 & \pm 8 & -2 \\
\hline 24D-20.1 & $\mathrm{m}, \mathrm{rex} / \mathrm{h}, \mathrm{p}$ & 12 & 0.03 & 0.003 & 0.38 & 1.456 & 2.7 & 0.3449 & 2.54 & 3685 & \pm 39 & +11 \\
\hline 24D-19.1 & $\mathrm{m}, \mathrm{rex} / \mathrm{h}, \mathrm{p}$ & 26 & 2.66 & 0.103 & 28.00 & 0.951 & 13.9 & 0.2035 & 67 & 2855 & \pm 1092 & -89 \\
\hline 24D-20.2 & $\mathrm{m}, \mathrm{rex} / \mathrm{h}, \mathrm{p}$ & 330 & 5.30 & 0.016 & 0.41 & 1.582 & 0.8 & 0.3224 & 0.32 & 3581 & \pm 5 & +15 \\
\hline
\end{tabular}


TABLE A1

(continued)

\begin{tabular}{|c|c|c|c|c|c|c|c|c|c|c|c|c|}
\hline Spot & site & $\begin{array}{c}\mathrm{U} \\
\mathrm{ppm}\end{array}$ & $\begin{array}{c}\text { Th } \\
\text { ppm }\end{array}$ & $\frac{\mathrm{Th}}{\mathrm{U}}$ & $\begin{array}{c}\% \\
{ }^{206} \mathrm{~Pb}_{\mathrm{c}}\end{array}$ & $\frac{{ }^{238} \mathrm{U}}{{ }^{206} \mathrm{~Pb}^{*}}$ & $\pm \%$ & $\frac{{ }^{207} \mathrm{~Pb}^{*}}{{ }^{206} \mathrm{~Pb}^{*}}$ & $\pm \%$ & $\frac{{ }^{207} \mathrm{Pl}}{{ }^{206} \mathrm{Pl}}$ & ge & $\begin{array}{c}\% \\
\text { Disc. }\end{array}$ \\
\hline $24 \mathrm{D}-21.1$ & $\mathrm{e}, \mathrm{sz}, \mathrm{p}$ & 29 & 0.47 & 0.016 & 0.41 & 1.284 & 1.8 & 0.3332 & 0.79 & 3632 & \pm 12 & -3 \\
\hline 24D-22.1 & e,rex,p & 100 & 0.55 & 0.006 & 0.07 & 1.291 & 1.0 & 0.3369 & 0.36 & 3649 & \pm 5 & -2 \\
\hline $24 \mathrm{D}-23.1$ & $\mathrm{~m}, \mathrm{osc}, \mathrm{p}$ & 17 & 0.06 & 0.003 & 0.34 & 1.331 & 2.2 & 0.3422 & 0.85 & 3673 & \pm 13 & +2 \\
\hline $24 D-23.2$ & $e, o s c+r e x, p$ & 106 & 0.78 & 0.007 & 0.26 & 1.286 & 1.1 & 0.3364 & 0.38 & 3646 & \pm 6 & -2 \\
\hline
\end{tabular}

Zircon morphology and analysis site: $\mathrm{p}=$ prism; $\mathrm{e}=$ equant grain; fr=grain fragment; $\mathrm{e}=$ grain end; $\mathrm{m}=$ mid-grain CL petrography: $\mathrm{osc}=$ oscillatory zoned; $\mathrm{h}=$ homogeneous, $\mathrm{sz}=$ sector $z$ oned; $\mathrm{rex}=$ recrystallized analyses in italics are ones with composite domains, and not used in age determinations $\%^{206} \mathrm{~Pb}_{\mathrm{c}}=$ percentage of ${ }^{206} \mathrm{~Pb}$ determined to be of non-radiogenic origin, based on measured ${ }^{204} \mathrm{~Pb} /{ }^{206} \mathrm{~Pb}$ ratio and Cumming and Richards model Pb compositions.

\section{REFERENCES}

Albaréde, F., 2009, Volatile accretion history of the terrestrial planets and dynamic implications: Nature, v. 461, p. 1227-1233, http://dx.doi.org/10.1038/nature08477

Allaart, J. H., 1976, The pre-3760 m.y. old supracrustal rocks of the Isua area, central West Greenland, and the associated occurrence of quartz-banded ironstone, in Windley, B. F., editor, The Early History of the Earth: London, Wiley, p. 177-189.

Amelin, Y., Kamo, S. L., and Lee, D. C., 2011, Evolution of early crust in chondritic or non-chondritic Earth inferred from $\mathrm{U}-\mathrm{Pb}$ and $\mathrm{Lu}-\mathrm{Hf}$ data for chemically abraded zircon from the Itsaq Gneiss Complex, West Greenland: Canadian Journal of Earth Sciences, v. 48, n. 2, p. 141-160, http://dx.doi.org/10.1139/E10091

Baadsgaard, H., Nutman, A. P., and Bridgwater, D., 1986a, Geochronology and isotope geochemistry of the early Archaean Amîtsoq gneisses of the Isukasia area, southern West Greenland: Geochimica et Cosmochimica Acta, v. 50, n. 10, p. 2173-2183, http://dx.doi.org/10.1016/0016-7037(86)90072-4

Baadsgaard, H., Nutman, A. P., Rosing, M., Bridgwater, D., and Longstaffe, F. J., 1986b, Alteration and metamorphism of Amîtsoq gneisses from the Isukasia area, West Greenland: Recommendation for isotope studies of the early crust: Geochimica et Cosmochimica Acta, v. 50, n. 10, p. 2165-2172, http://dx.doi.org/10.1016/0016-7037(86)90071-2

Bennett, V. C., Nutman, A. P., and McCulloch, M. T., 1993, Nd isotopic evidence for transient, highly depleted mantle reservoirs in the early history of the Earth: Earth and Planetary Science Letters, v. 119 n. 3, p. 299-317, http://dx.doi.org/10.1016/0012-821X(93)90140-5

Bennett, V. C., Nutman, A. P., and Esat, T. M., 2003, Constraints on mantle evolution and differentiation from ${ }^{187} \mathrm{Os} /{ }^{188} \mathrm{Os}$ isotopic compositions of Archaean ultramafic rocks from southern West Greenland $(3.8 \mathrm{Ga})$ and Western Australia $(3.46 \mathrm{Ga})$ : Geochimica et Cosmochimica Acta, v. 66, n. 14, p. $2615-$ 2630, http://dx.doi.org/10.1016/S0016-7037(02)00862-1

Bennett, V. C., Brandon, A. D., and Nutman, A. P., 2007, Coupled ${ }^{142} \mathrm{Nd}-{ }^{143} \mathrm{Nd}$ isotopic evidence for hadean mantle dynamics: Science, v. 318, n. 5858, p. 1907-1910, http://dx.doi.org/10.1126/science.1145928

Black, L. P., Gale, N. H., Moorbath, S., Pankhurst, R. J., and McGregor, V. R., 1971, Isotopic dating of very early Precambrian amphibolite facies gneisses from the Godthåb district, West Greenland: Earth and Planetary Science Letters, v. 12, n. 3, p. 245-259, http://dx.doi.org/10.1016/0012-821X(71)90208-1

Bohlar, R., Kamber, B. S., Moorbath, S., Fedo, C. M., and Whitehouse, M. J., 2004, Characterisation of early Archaean chemical sediments by trace element signatures: Earth and Planetary Science Letters, v. 222, n. 1, p. 43-60, http://dx.doi.org/10.1016/j.epsl.2004.02.016

Bohlar, R., Kamber, B. S., Moorbath, S., Whitehouse, M. J., and Collerson, K. D., 2005, Chemical characterization of earth's most ancient clastic metasediments from Isua: Geochimica et Cosmochimica Acta, v. 69, n. 6, p. 1555-1573, http://dx.doi.org/10.1016/j.gca.2004.09.023

Bowring, S., and Williams, I. S., 1999, Priscoan (4.00-4.03 Ga) orthogneisses from northwestern Canada: Contributions to Mineralogy and Petrology, v. 134, n. 1, p. 3-16, http://dx.doi.org/10.1007/ s004100050465

Bridgwater, D., and McGregor, V. R., 1974, Field work on the very early Precambrian rocks of the Isua area, southern West Greenland: Rapport Grønlands Geologiske Undersøgelse, v. 65, p. 49-54.

Caro, G., Bourdon, B., Birk, J.-L., and Moorbath, S., 2006, High-precision ${ }^{142} \mathrm{Nd} /{ }^{144} \mathrm{Nd}$ measurements in terrestrial rocks: Constraints on the early differentiation of Earth's mantle: Geochimica et Cosmochimica Acta, v. 70, n. 1, p. 164-191, http://dx.doi.org/10.1016/j.gca.2005.08.015

Chadwick, B., and Crewe, M. A., 1986, Chromite in the early Archaean Akilia association (c. 3,800 m.y.), Ivisârtoq region, inner Godthåbsfjord, southern West Greenland: Economic Geology, v. 81, p. 184-191, http:/ /dx.doi.org/10.2113/gsecongeo.81.1.184

Compston, W., Kinny, P. D., Williams, I. S., and Foster, J. J., 1986, The age and Pb loss behaviour of zircons from the Isua supracrustal belt as determined by ion microprobe: Earth and Planetary Science Letters, v. 80, n. 1-2, p. 71-81, http://dx.doi.org/10.1016/0012-821X(86)90020-8

Craddock, P. R., and Dauphas, N., 2011, Iron and carbon isotope evidence for microbial iron respiration 
throughout the Archean: Earth and Planetary Science Letters, v. 303, p. 121-132, http://dx.doi.org/ 10.1016/j.epsl.2010.12.045

Crowley, J. L., 2002, Testing the model of late Archean terrane accretion in southern West Greenland: a comparison of timing of geological events across the Qarliit nunaat fault, Buksefjorden region: Precambrian Research, v. 116, n. 1-2, p. 57-79, http://dx.doi.org/10.1016/S0301-9268(02)00002-5

2003, U-Pb geochronology of $3810-3630$ Ma granitoid rocks south of the Isua greenstone belt, southern West Greenland: Precambrian Research, v. 126, n. 3-4, p. 235-257, http://dx.doi.org/10.1016/ S0301-9268(03)00097-4

Crowley, J. L., Myers, J. S., and Dunning, G. R., 2002, Timing and nature of multiple 3700-3600 Ma tectonic events in granitoid rocks north of the Isua greenstone belt, southern West Greenland: Geological Society of America Bulletin, v. 114, n. 10, p. 1311-1325, http://dx.doi.org/10.1130/00167606(2002) 114〈1311:TANOMM $\rangle 2.0 . C O ; 2$

Cumming, G. L., and Richards, J. R., 1975, Ore lead ratios in a continuously changing Earth: Earth and Planetary Science Letters, v. 28, n. 2, p. 155-171, http://dx.doi.org/10.1016/0012-821X(75)90223-X

Dauphas, N., Van Zuilen, M., Wadhwa, M., Davis, A. M., Marty, B., and Janney, P. E., 2004, Clues from Fe isotope variations on the origin of early Archean BIFs from Greenland: Science, v. 306, n. 5704, p. 2077-2080, http://dx.doi.org/10.1126/science.1104639

Dilek, Y., and Polat, A., 2008, Suprasubduction zone ophiolites and Archean tectonics: Geology, v. 36, n. 5, p. 431-432, http://dx.doi.org/10.1130/Focus052008.1

Duclaux, G., Rey, P., Guillot, S., and Ménot, R. P., 2007, Orogen-parallel flow during continental convergence: Numerical experiments and Archaean field examples: Geology, v. 35, n. 8, p. 715-718, http:// dx.doi.org/10.1130/G23540A.1

Dymek, R. F., and Klein, C., 1988, Chemistry, petrology and origin of banded iron-formation lithologies from the 3800 Ma Isua supracrustal belt, West Greenland: Precambrian Research, v. 39, n. 4, p. 247-302, http://dx.doi.org/10.1016/0301-9268(88)90022-8

Dymek, R. F., Brothers, S. C., and Schiffries, C. M., 1988, Petrogenesis of ultramafic metamorphic rocks from the 3800 Ma Isua supracrustal belt, West Greenland: Journal of Petrology, v. 29, n. 6, p. 1353-1397, http://dx.doi.org/10.1093/petrology/29.6.1353

Fan, W. M., Zhang, H. F., Baker, J., Jarvis, K. E., Mason, P. R. D., and Menzies, M., 2000, On and off the North China Craton: Where is the Archaean keel?: Journal of Petrology, v. 41, n. 7, p. 933-950, http:// dx.doi.org/10.1093/petrology/41.7.933

Friend, C. R. L., and Nutman, A. P., 2005a, Complex 3670-3500 Ma orogenic episodes superimposed on juvenile crust accreted between 3850-3690 Ma, Itsaq Gneiss Complex, southern West Greenland: Journal of Geology, v. 113, p. 375-398, http://dx.doi.org/10.1086/430239

2005b, New pieces to the Archaean terrane jigsaw puzzle in the Nuuk region, southern West Greenland: Steps in transforming a simple insight into a complex regional tectonothermal model: Journal of the Geological Society, London, v. 162, n. 1, p. 147-163, http://dx.doi.org/10.1144/0016764903-161

2010, Eoarchean ophiolites? New evidence for the debate on the Isua supracrustal belt, southern West Greenland: American Journal of Science, v. 310, n. 9, p. 826-861, http://dx.doi.org/10.2475/ 09.2010 .04

_ 2011, Dunites from Isua, Greenland: A ca. 3720 Ma window into subcrustal metasomatism of depleted mantle: Geology, v. 39, n. 7, p. 663-666, http://dx.doi.org/10.1130/G31904.1

Friend, C. R. L., Nutman, A. P., and McGregor, V. R., 1987, Late-Archaean tectonics in the Faeringehavn-Tre Brødre area, south of Buksefjorden, southern West Greenland: Journal of the Geological Society, London, v. 144, n. 3, p. 369-376, http://dx.doi.org/10.1144/gsjgs.144.3.0369

_ 1988, Late Archaean terrane accretion in the Godthåb region, southern West Greenland: Nature, v. 335, p. 535-538, http://dx.doi.org/10.1038/335535a0

Friend, C. R. L., Bennett, V. C., and Nutman, A. P., 2002, Abyssal peridotites >3,800 Ma from southern West Greenland: field relationships, petrography, geochronology, whole-rock and mineral chemistry of dunite and harzburgite inclusions in the Itsaq Gneiss Complex: Contributions to Mineralogy and Petrology, v. 143, n. 1, p. 71-92, http://dx.doi.org/10.1007/s00410-001-0332-7

Friend, C. R. L., Nutman, A. P., Bennett, V. C., and Norman, M. D., 2008, Seawater-like trace element signatures $(\mathrm{REE}+\mathrm{Y})$ from Eoarchaean chemical sedimentary rocks from southern West Greenland, and their corruption during high-grade metamorphism: Contributions to Mineralogy and Petrology, v. 155 n. 2, p. 229-246, http://dx.doi.org/10.1007/S00410-007-0239-z

Furnes, H., de Wit, M., Staudigel, H., Rosing, M., and Muehlenbachs, K., 2007, A vestige of Earth's oldest ophiolite: Science, v. 215, n. 5819, p. 1704-1707, http://dx.doi.org/10.1126/science.1139170

Griffin, W. L., McGregor, V. R., Nutman, A. P., Taylor, P. N., and Bridgwater, D., 1980, Early Archaean granulite-facies metamorphism south of Ameralik: Earth and Planetary Science Letters, v. 50, n. 1, p. 59-74, http://dx.doi.org/10.1016/0012-821X(80)90119-3

Hamilton, P. J., O'Nions, R. K., Evensen, N. H., Bridgwater, D., and Allaart, J. H., 1978, Sm-Nd isotopic investigations of Isua supracrustals and implications for mantle evolution: Nature, v. 272, p. 41-43, http://dx.doi.org/10.1038/272041a0

Hiess, J., Bennett, V. C., Nutman, A. P., and Williams, I. S., 2009, In situ U-Pb, O and Hf isotopic compositions of zircon and olivine from Eoarchaean rocks, West Greenland: New insights to making old crust: Geochimica et Cosmochimica Acta, v. 73, p. 4489-4516, http://dx.doi.org/10.1016/ j.gca.2009.04.019

2011, Archaean fluid-assisted crustal cannibalism recorded by low $\delta^{18} \mathrm{O}$ and negative $\varepsilon_{\mathrm{Hf}}(\mathrm{T})$ isotopic signatures of West Greenland granite zircon: Contributions to Mineralogy and Petrology, v. 161, n. 6 , p. 1027-1050, http://dx.doi.org/10.1007/s00410-010-0578-z

Hoffmann, J. E., Münker, C., Polat, A, König, S., Mezger, K., and Rosing, M. T., 2010, Highly depleted 
Hadean mantle reservoirs in the sources of early Archean arc-like rocks, Isua supracrustal belt, southern West Greenland: Geochimica et Cosmochimica Acta, v. 74, n. 24, p. 7236-7260, http://dx.doi.org/ 10.1016/j.gca.2010.09.027

Hoffmann, J. E., Münker, C., Naeraa, T., Rosing, M. T., Garbe-Schönberg D., and Svahnberg, H., 2011a, Mecahisms of Archean crust production inferred from high precision HFS systematics in TTGs: Geochimica et Cosmochimica Acta, v. 75, n. 15, p. 4175-4178, http://dx.doi.org/10.1016/ j.gca.2011.04.027

Hoffmann, J. E., Münker, C., Polat, A., Rosing, M. T., and Schulz, T., 2011b, The origin of decoupled Hf-Nd isotope compositions in Eoarchean rocks from southern West Greenland: Geochimica et Cosmochimica Acta, v. 75, n. 21, p. 6610-6628, http://dx.doi.org/10.1016/j.gca.2011.08.018

Hollister, L. S., and Crawford, M. L., 1986, Melt-enhanced deformation: A major tectonic process: Geology, v. 14, n. 7, p. 558-561, http://dx.doi.org/10.1130/0091-7613(1986) 14〈558:MDAMTP $\rangle 2.0 . C O ; 2$

Horie, K., Nutman, A. P., Friend, C. R. L., and Hidaka, H., 2010, The complex age of orthogneiss protoliths exemplified by the Eoarchaean Itsaq Gneiss Complex (Greenland): SHRIMP and old rocks: Precambrian Research, v. 181, n. 1, p. 25-43, http://dx.doi.org/10.1016/j.precamres.2010.06.016

Iizuka, T., Komiya, T., Ueno, Y., Katayama, I., Uehara, Y., Maruyama, S., Hirata, T., Johnson, S. P., and Dunkley, D. J., 2007, Geology and zircon geochronology of the Acasta Gneiss Complex, northwestern Canada: New constraints on its tectonothermal history: Precambrian Research, v. 153, n. 3-4, p. 179 208, http://dx.doi.org/10.1016/j.precamres.2006.11.017

Jacobsen, S. B., and Dymek, R. F., 1987, Nd and Sr isotope systematics of clastic metasediments from Isua, West Greenland: Identification of pre-3.8 Ga differentiated crustal components: Journal of Geophysical Research, v. 93, n. B1, p. 338-354, http://dx.doi.org/10.1029/JB093iB01p00338

Jenner, F. E., Bennett, V. C., Nutman, A. P., Friend, C. R. L., Norman, M. D., and Yaxley, G., 2009, Evidence for subduction at $3.8 \mathrm{Ga}$ : Geochemistry of arc-like metabasalts from the southern edge of the Isua Supracrustal Belt: Chemical Geology, v. 261, n. 1-2, p. 83-98, http://dx.doi.org/10.1016/j.chemgeo. 2008.09.016

Kamber, B. S., and Moorbath, M., 1998, Initial Pb of the Amîtsoq gneiss revisited: implication for the timing of early Archaean crustal evolution in West Greenland: Chemical Geology, v. 150, n. 1-2, p. 19-41, http:/ /dx.doi.org/10.1016/S0009-2541(98)00059-X

Kamber, B. S., Collerson, K. D., Moorbath, S., and Whitehouse, M. J., 2003, Inheritance of early Archean $\mathrm{Pb}$-isotope variability from long-lived Hadean protocrust: Contributions to Mineralogy and Petrology, v. 145, n. 1, p. 25-46, http://dx.doi.org/10.1007/s00410-002-0429-7

Kamber, B. S., Whitehouse, M. J., Bolhar, R., and Moorbath, S., 2005, Volcanic resurfacing and the early terrestrial crust: Zircon U-Pb and REE constraints from the Isua Greenstone Belt, southern West Greenland: Earth and Planetary Science Letters, v. 240, n. 2, p. 276-290, http://dx.doi.org/10.1016/ j.epsl.2005.09.037

Kemp, A. I. S., Foster, G. L., Scherstén, A., Whitehouse, M. J., Darling, J., and Storey, C., 2009, Concurrent $\mathrm{Pb}-\mathrm{Hf}$ isotope analysis of zircon by laser ablation multi-collector ICP-MS, with implications for the crustal evolution of Greenland and the Himalayas: Chemical Geology, v. 261, n. 3-4, p. 244-260, http://dx.doi.org/10.1016/j.chemgeo.2008.06.019

Kinny, P. D., 1986, 3820 Ma zircons from a tonalitic Amîtsoq gneiss in the Godthåb district of southern West Greenland: Earth and Planetary Science Letters, v. 79, n. 3-4, p. 337-347, http://dx.doi.org/10.1016/ 0012-821X(86)90190-1

1987, ms, An ion-microprobe study of uranium-lead and hafnium isotopes in natural zircon Canberra, Australia, Australian National University, Ph. D. Thesis, 160 p.

Kinny, P. D., and Nutman, A. P., 1996, Zirconology of the Meeberrie gneiss, Yilgarn Craton, Western Australia: an early Archaean migmatite: Precambrian Research, v. 78, n. 1-3, p. 165-178, http:// dx.doi.org/10.1016/0301-9268(95)00076-3

Komiya, T., Maruyama, S., Masuda, T., Nohda, S., Hayashi, M., and Okamoto, K., 1999, Plate Tectonics at 3.8-3.7 Ga: Field evidence from the Isua accretionary complex, Southern West Greenland: Journal of Geology, v. 107, n. 5, p. 515-554, http://dx.doi.org/10.1086/314371

Liu, D., Wan, Y., Wu, J. S., Wilde, S. A., Zhou, H. Y., Dong, C. Y., and Yin, X. Y., 2007, Eoarchean rocks and zircons in the North China Craton, in van Kranendonk, M. J., Smithies, R. H., and Bennett, V. C., editors, Earth's Oldest Rocks: The Netherlands, Elsevier, Developments in Precambrian Geology, v. 15, p. 251-273, http://dx.doi.org/10.1016/S0166-2635(07)15035-0

McCulloch, M. T., and Woodhead, J. D., 1993, Lead isotopic evidences for deep crustal-scale fluid transport during granite petrogenesis: Geochimica et Cosmochimica Acta, v. 57, n. 3, p. 659-674, http:// dx.doi.org/10.1016/0016-7037(93)90376-8

McGregor, V. R., 1968, Field evidence of very old Precambrian rocks in the Godthåb area, West Greenland: Rapport Grønlands Geologiske Undersøgelse, v. 15, p. 31-35.

1973, The early Precambrian gneisses of the Godthåb district, West Greenland: Philosophical Transactions of the Royal Society of London A, v. A273, p. 343-358, http://dx.doi.org/10.1098/ rsta. 1973.0005

2000, Initial $\mathrm{Pb}$ of the Amîtsoq gneiss revisited: Implications for the timing of early Archaean crustal evolution in West Greenland-Comment: Chemical Geology, v. 166, n. 3-4, p. 301-308, http:// dx.doi.org/10.1016/S0009-2541(99)00224-7

McGregor, V. R., and Mason, B., 1977, Petrogenesis and geochemistry of metabasaltic and metasedimentary enclaves in the Amîtsoq gneisses, West Greenland: American Mineralogist, v. 62, n. 9-10, p. 887-904.

McGregor, V. R., Friend, C. R. L., and Nutman, A. P., 1991, The late Archaean mobile belt through Godthåbsfjord, southern West Greenland: a continent-continent collision zone?: Bulletin of the Geological Society of Denmark, v. 39, p. 179-197. 
Moorbath, S., 1975, Evolution of Precambrian crust from strontium isotopic evidence: Nature, v. 254, p. 395-398, http://dx.doi.org/10.1038/254395a0

1994, Age of the oldest rocks with biological components: Journal of Biological Physics, v. 20, n. 1-4, p. 85-94, http://dx.doi.org/10.1007/BF00700424

2005, Oldest rocks, earliest life, heaviest impacts, and the Hadean-Archaean transition: Applied Geochemistry, v. 20, n. 5, p. 819-824, http://dx.doi.org/10.1016/j.apgeochem.2005.01.001

Moorbath, S., O’Nions, R. K., Pankhurst, R. J., Gale, N. H., and McGregor, V. R., 1972, Further rubidiumstrontium age determinations on the very early Precambrian rocks of the Godthåb district, West Greenland: Nature, v. 240, n. 100, p. 78-82, http://dx.doi.org/10.1038/physci240078a0

Moorbath, S., O'Nions, R. K., and Pankhurst, R. J., 1973, Early Archaean age for the Isua iron formation, West Greenland: Nature, v. 245, p. 138-139, http://dx.doi.org/10.1038/245138a0

Moorbath, S., Allaart, J. H., Bridgwater, D., and McGregor, V. R., 1977, Rb-Sr ages of early Archaean supracrustal rocks and Amîtsoq gneisses at Isua: Nature, v. 270, p. 43-45, http://dx.doi.org/10.1038/ $270043 \mathrm{a} 0$

Myers, J. S., 2001, Protoliths of the 3.8-3.7 Ga Isua greenstone belt, West Greenland: Precambrian Research, v. 105, n. 2-4, p. 129-141, http://dx.doi.org/10.1016/S0301-9268(00)00108-X

Naeraa, T., Scherstén, A., Rosing, M. T., Kemp, A. I. S., Hoffmann, J. E., Kokfelt, T. F., and Whitehouse, M. J., 2012, Hafnium isotope evidence for the transition in the dynamics of continental growth 3.2 Gyr ago: Nature, v. 485, p. 627-630, http://dx.doi.org/10.1038/nature11140

Nagel, T. J., Hoffmann, J. E., and Münker, K., 2012, Generation of Eoarchean tonalite-trondhjemitegranodiorite series from thickened mafic arc crust: Geology, v. 40, n. 4, p. 375-378, http://dx.doi.org/ $10.1130 / \mathrm{G} 32729.1$

Nutman, A. P., 1984, Early Archaean crustal evolution of the Isukasia area, southern West Greenland in Kröner, A., and Greiling, R., editors, Precambrian Tectonics Illustrated: Stuttgart, E. Schweitzerbart'sche Verlagsbuchhandlung, p. 79-93.

2006, Antiquity of the oceans and continents: Elements, v. 2, n. 4, p. 223-227, http://dx.doi.org/ 10.2113 /gselements.2.4.223

Nutman, A. P., and Bridgwater, D., 1986, Early Archaean Amîtsoq tonalites and granites from the Isukasia area, southern West Greenland: Development of the oldest-known sial: Contributions to Mineralogy and Petrology, v. 94, n. 2, p. 137-148, http://dx.doi.org/10.1007/BF00592931

Nutman, A. P., and Friend, C. R. L., 2007a, Adjacent terranes with $c a .2715$ and 2650 Ma high-pressure metamorphic assemblages in the Nuuk region of the North Atlantic Craton, southern West Greenland: Complexities of Neoarchaean collisional orogeny: Precambrian Research, v. 155, n. 3-4, p. 159-203, http://dx.doi.org/10.1016/j.precamres.2006.12.009

— 2009, New 1:20000 geological maps, synthesis and history of the Isua supracrustal belt and adjacent orthogneisses, southern West Greenland: A glimpse of Eoarchaean crust formation and orogeny: Precambrian Research, v. 172, n. 3-4, p. 189-211, http://dx.doi.org/10.1016/j.precamres.2009.03.017

Nutman, A. P., Allaart, J. H., Bridgwater, D., Dimroth, E., and Rosing, M. T., 1984a, Stratigraphic and geochemical evidence for the depositional environment of the early Archaean Isua supracrustal belt, southern West Greenland: Precambrian Research, v. 25, p. 365-396.

Nutman, A. P., Bridgwater, D., and Fryer, B., 1984b, The iron rich suite from the Amîtsoq gneisses of southern West Greenland: Early Archaean plutonic rocks of mixed crustal and mantle origin: Contributions to Mineralogy and Petrology, v. 87, n. 1, p. 24-34, http://dx.doi.org/10.1007/BF00371399

Nutman, A. P., Friend, C. R. L., Baadsgaard, H., and McGregor, V. R., 1989, Evolution and assembly of Archaean gneiss terranes in the Godthåbsfjord region, southern West Greenland: structural, metamorphic and isotopic evidence: Tectonics, v. 8, n. 3, p. 573-589, http://dx.doi.org/10.1029/ TC008i003p00573

Nutman, A. P., Kinny, P. D., Compston, W., and Williams, I. S., 1991, SHRIMP U-Pb zircon geochronology of the Narryer Gneiss Complex, Western Australia: Precambrian Research, v. 52, n. 4, p. 275-300, http:// dx.doi.org/10.1016/0301-9268(84)90010-X

Nutman, A. P., Friend, C. R. L., Kinny, P. D., and McGregor, V. R., 1993, Anatomy of an Early Archaean gneiss complex: 3900 to 3600 Ma crustal evolution in southern West Greenland: Geology, v. 21, n. 5, p. 415-418, http://dx.doi.org/10.1130/0091-7613(1993)021<0415:AOAEAG >2.3.CO;2

Nutman, A. P., McGregor, V. R., Friend, C. R. L., Bennett, V. C., and Kinny, P. D., 1996, The Itsaq Gneiss Complex of southern West Greenland; the world's most extensive record of early crustal evolution (3900-3600 Ma): Precambrian Research, v. 78, n. 1-3, p. 1-39, http://dx.doi.org/10.1016/03019268(95) 00066-6

Nutman, A. P., Bennett, V. C., Friend, C. R. L., and Rosing, M. T., 1997a, 3710 and 3790 Ma volcanic sequences in the Isua (Greenland) supracrustal belt; structural and $\mathrm{Nd}$ isotope implications: Chemical Geology, v. 141, n. 3-4, p. 271-287, http://dx.doi.org/10.1016/S0009-2541(97)00084-3

Nutman, A. P., Mozjsis, S., and Friend, C. R. L., 1997b, Recognition of $\geq 3850$ Ma water-lain sediments in West Greenland and their significance for the early Archaean Earth: Geochimica et Cosmochimica Acta, v. 61, n. 12, p. 2475-2484, http://dx.doi.org/10.1016/S0016-7037(97)00097-5

Nutman, A. P., Bennett, V. C., Friend, C. R. L., and Norman, M., 1999, Meta-igneous (non-gneissic) tonalites and quartz-diorites from an extensive ca. 3800 Ma terrain south of the Isua supracrustal belt, southern West Greenland: constraints on early crust formation: Contributions to Mineralogy and Petrology, v. 137, n. 4, p. 364-388, http://dx.doi.org/10.1007/s004100050556

Nutman, A. P., Bennett, V. C., Friend, C. R. L., and McGregor, V. R., 2000, The early Archaean Itsaq Gneiss Complex of southern West Greenland: The importance of field observations in interpreting dates and isotopic data constraining early terrestrial evolution: Geochimica et Cosmochimica Acta, v. 64, n. 17, p. 3035-3060, http://dx.doi.org/10.1016/S0016-7037(99)00431-7

Nutman, A. P., McGregor, V. R., Shiraishi, K., Friend, C. R. L., Bennett, V. C., and Kinny, P. D., 2002a, $\geq 3850$ 
Ma BIF and mafic inclusions in the early Archaean Itsaq Gneiss Complex around Akilia, southern West Greenland? The difficulties of precise dating of zircon-free protoliths in migmatites: Precambrian Research, v. 117, n. 3-4, p. 185-224, http://dx.doi.org/10.1016/S0301-9268(02)00045-1

Nutman, A. P., Friend, C. R. L., and Bennett, V. C., 2002b, Evidence for 3650-3600 Ma assembly of the northern end of the Itsaq Gneiss Complex, Greenland: Implication for early Archean tectonics: Tectonics, v. 21, n. 1, p. 5-1-5-28, http://dx.doi.org/10.1029/2000TC001203

Nutman, A. P., Friend, C. R. L., Bennett, V., and McGregor, V. R., 2004a, Dating of the Ameralik dyke swarms of the Nuuk district, southern West Greenland: mafic intrusion events starting from c. 3510 Ma: Journal of the Geological Society, London, v. 161, p. 421-430, http://dx.doi.org/10.1144/0016-764903-043

Nutman, A. P., Friend, C. R. L., Barker, S. S., and McGregor, V. R., 2004b, Inventory and assessment of Palaeoarchaean gneiss terrains and detrital zircons in southern West Greenland: Precambrian Research, v. 135, n. 4, p. 281-314, http://dx.doi.org/10.1016/j.precamres.2004.09.002

Nutman, A. P., Friend, C. R. L., Horie, H., and Hidaka, H., 2007a, The Itsaq Gneiss Complex of southern West Greenland and the Construction of Eoarchaean Crust at Convergent Plate Boundaries, in van Kranendonk, M. J., Smithies, R. H., and Bennett, V. C., editors, Earth's Oldest Rocks: The Netherlands, Elsevier, Developments in Precambrian History, v. 15, p. 187-218, http://dx.doi.org/10.1016/S01662635(07) 15033-7

Nutman, A. P., Bennett, V. C., Friend, C. R. L., Horie, K., and Hidaka, H., 2007b, 3850 Ma tonalites in the Nuuk region, Greenland: Geochemistry and their reworking within an Eoarchaean gneiss complex: Contributions to Mineralogy and Petrology, v. 154, n. 4, p. 385-408, http://dx.doi.org/10.1007/s00410007-0199-3

Nutman, A. P., Friend, C. R. L., and Paxton, S., 2009, Detrital zircon sedimentary provenance ages for the Eoarchaean Isua supracrustal belt southern West Greenland: Juxtaposition an imbricated ca. $3700 \mathrm{Ma}$ juvenile arc against an older complex with 3920-3800 Ma components: Precambrian Research, v. 172, n. 3-4, p. 212-233, http://dx.doi.org/10.1016/j.precamres.2009.03.019an

Nutman, A. P., Friend, C. R. L., Bennett, V. C., Wright, D., and Norman, M. D., 2010, $\geq 3700$ Ma pre-metamorphic dolomite formed by microbial mediation in the Isua supracrustal belt (W. Greenland): Simple evidence for early life?: Precambrian Research, v. 183, n. 4, p. 725-737, http://dx.doi.org/ 10.1016/j.precamres.2010.08.006

Nutman, A. P., Bennett, V. C., and Friend, C. R. L., 2011, Waves and weathering at 3.7 Ga: Geologic evidence for an equitable climate under the faint early Sun: Australian Journal of Earth Sciences, v. 59, n. 2, p. 167-176, http://dx.doi.org/10.1080/08120099.2012.618512

2013, The emergence of the Eoarchaean proto-arc: evolution of a $c .3700$ Ma convergent plate boundary at Isua, southern West Greenland, in Roberts, N. M. W., van Kranendonk, M., Parman, S., Shirey, S., and Clift, P. D., editors, Continent Formation Through Time: Geological Society, London, Special Publications, v. 389, http://doi.org/10.1144/SP389.5.

O’Neil, J., Maurice, C., Stevenson, R. K., Larocque, J., Cloquet, C., David, J., and Francis, D., 2007, The geology of the $3.8 \mathrm{Ga}$ Nuvvuagittuq (Porpoise Cove) greenstone belt, northeastern Superior Province, Canada in van Kranendonk, M. J., Smithies, R. H., and Bennett, V. C., editors, Earth's Oldest Rocks: The Netherlands, Elsevier, Developments in Precambrian Geology, v. 15, p. 219-250, http://dx.doi.org/ 10.1016/S0166-2635(07) 15034-9

Polat, A., and Hofmann, A. W., 2003, Alteration and geochemical patterns in the 3.7-3.8 Ga Isua greenstone belt, West Greenland: Precambrian Research, v. 126, n. 3-4, p. 197-218, http://dx.doi.org/10.1016/ S0301-9268(03)00095-0

Polat, A., Hofmann, A. W., and Rosing, M. T., 2002, Boninite-like volcanic rocks in the 3.7-3.8 Ga Isua greenstone belt, West Greenland: geochemical evidence for intra-oceanic subduction zone processes in the early Earth: Chemical Geology, v. 184, n. 3-4, p. 231-254, http://dx.doi.org/10.1016/S00092541(01) 00363-1

Pope, E. C., Bird, D. K., and Rosing, M. T., 2012, Isotope composition and volume of Earth's early oceans: Proceedings of the National Academy of Sciences of the United States of America, v. 109, n. 12, p. 4371-4376, http://dx.doi.org/10.1073/pnas.1115705109

Ren, J., Tamaki, K., Li, S., and Zhang, J., 2002, Late Mesozoic and Cenozoic rifting and its dynamic setting in Eastern China and adjacent areas: Tectonophysics, v. 344, n. 3-4, p. 175-205, http://dx.doi.org/ 10.1016/S0040-1951(01)00271-2

Rey, P., and Coltice, N., 2008, A Neoarchean lithospheric strengthening and the coupling of Earth's geochemical reservoirs: Geology, v. 36, n. 8, p. 635-638, http:/ /dx.doi.org/10.1130/G25031A.1

Rizo, H., Boyet, M., Blichert-Toft, J., and Rosing, M. T., 2011, Combined Nd and Hf isotope evidence for deep-seated source of Isua lavas: Earth and Planetary Science Letters, v. 312, n. 3-4, p. 267-279, http://dx.doi.org/10.1016/j.epsl.2011.10.014

Rosing, M. T., 1999, 13C-depleted carbon microparticles in $>3700$ Ma sea-floor sedimentary rocks from West Greenland: Science, v. 283, n. 5402, p. 674-676, http://dx.doi.org/10.1126/science.283.5402.674

Rosing, M. T., Rose, N. M., Bridgwater, D., and Thomsen, H. S., 1996, Earliest part of the Earth's stratigraphic record: A reappraisal of the $>3.7$ Ga Isua (Greenland) supracrustal sequence: Geology, v. 24, n. 1, p. 43-46, http://dx.doi.org/10.1130/0091-7613(1996)024〈0043:EPOESS〉2.3.CO;2

Sandiford, M., 1989, Horizontal structures in granulite terrains: A record of mountain building or mountain collapse?: Geology, v. 17, n. 5, p. 449-452, http://dx.doi.org/10.1130/0091-7613(1989)017〈0449: HSIGTA)2.3.CO;2

Schiøtte, L., Compston, W., and Bridgwater, D., 1989a, Ion probe U-Th-Pb zircon dating of polymetamorphic orthogneisses from northern Labrador, Canada: Canadian Journal of Earth Sciences, v. 26, n. 8, p. 1533-1556, http://dx.doi.org/10.1139/e89-131

1989b, U-Pb single zircon age for the Tinissaq gneiss of southern West Greenland: A controversy resolved: Chemical Geology, v. 79, n. 1, p. 21-30, http://dx.doi.org/10.1016/0168-9622(89)90004-3 
Shervais, J. W., 2001, Birth, death, and resurrection: The life cycle of suprasubduction zone ophiolites: Geochemistry, Geophysics, Geosystems, v. 2, n. 1, paper number 2000GC000080, http://dx.doi.org/ 10.1029/2000GC000080

Solvang, M., 1999, An investigation of metavolcanic rocks from the eastern part of the Isua greenstone belt, Western Greenland: Copenhagen, Denmark, Geological Survey of Denmark and Greenland (GEUS) Internal Report, $62 \mathrm{p}$.

Steenfelt, A., Garde, A. A., and Moyen, J.-F., 2005, Mantle wedge involvement in the petrogenesis of Archaean grey gneisses in West Greenland: Lithos, v. 79, n. 1-2, p. 207-228, http://dx.doi.org/10.1016/ j.lithos.2004.04.054

Tera, F. 2003, A lead isotope method for the accurate dating of disturbed geologic systems: numerical demonstrations, some applications and implications: Geochimica et Cosmochimica Acta, v. 67, n. 19, p. 3687-3715, http:/ / dx.doi.org/10.1016/S0016-7037(03)00132-7

Wei, W., Xu, J. D., Zhao, D. P., and Shi, Y. L., 2012, East Asia mantle tomography: New insight into plate subduction and intraplate volcanism: Journal of Asian Earth Sciences, v. 60, p. 88-103, http://dx.doi.org/ 10.1016/j.jseaes.2012.08.001

White, R. V., Crowley, J. L., and Myers, J. S., 2000, Earth's oldest well-preserved mafic dyke swarms in the vicinity of the Isua greenstone belt, southern West Greenland: Geology of Greenland Survey Bulletin, v. 186 , p. $65-72$.

Whitehouse, M. J., Kamber, B. S., and Moorbath, S., 1999, Age significance of U-Th-Pb zircon data from early Archaean rocks of west Greenland-a reassessment based on combined ion-microprobe and imaging studies: Chemical Geology, v. 160, n. 3, p. 201-224, http://dx.doi.org/10.1016/S0009-2541(99)00066-2

Willbold, M., Elliott, T., and Moorbath, S., 2011, The tungsten isotopic composition of the Earth's mantle before the terminal bombardment: Nature, v. 477, n. 7363, p. 195-198, http://dx.doi.org/10.1038/ nature 10399

Yang, J.-H., Wu, F.-Y., Chung, S.-L., Lo, C.-H., Wilde, S. A., and Davis, G. A., 2007, Rapid exhumation of the Liaonan metamorphic core complex: Inferences from ${ }^{40} \mathrm{Ar} /{ }^{39} \mathrm{Ar}$ thermochronology and implications for Late Mesozoic extension in the eastern North China Craton: Geological Society of America Bulletin, v. 119, n. 11-12, p. 1405-1414, http://dx.doi.org/10.1130/B26085.1 